\title{
TFRS 16 Standardının Seçilmiş BiST 100 Şirketlerinin Finansal Tabloları ve Finansal Performanslarına Etkisinin İncelenmesi ${ }^{1}$
}

Investigation of the Impact of TFRS 16 Standard on the Financial Statements and Financial Performance of BIST 100 Companies

\section{Dr. Öğr. Üyesi Emre Selçuk SARI² - Arş. Grv. Nevzat GÜNGÖR ${ }^{3}$}

Başvuru Tarihi: 04.08.2019

Kabul Tarihi: 05.08.2020

Makale Türü: Araştırma Makalesi

Öz

Yıllar içerisinde, Finansal Muhasebe Standartları Kurulu (FMSK) ve Uluslararası Muhasebe Standartları Kurulu (UMSK) tartışmalı finansal kiralama kurallarında sayısız değişiklik yapmıştır. UMSK tarafindan yayınlanan Uluslararası Finansal Raporlama Standardı (UFRS) 16 Finansal Kiralama Standardı (Türkiye'de Kamu Gözetimi Muhasebe ve Denetim Standartları Kurumu (KGK) tarafindan Türkiye Finansal Raporlama Standardı (TFRS) 16 olarak yayımlanmıştır) 1 Ocak 2019 tarihinden itibaren uygulanmaya başlanmıştır. Bu çalışmanın amacı, yeni finansal kiralama standardının BİST 100 endeksinde faaliyet gösteren şirketlerin ve sektörlerin finansal tabloları ve oranları üzerindeki etkisini çeşitli varsayımlar altında analiz etmektir.

Bu çalışmada BİST 100'de listelenen üretim şirketlerinin finansal tabloları ve açıklamaları incelenmiştir. Çeşitli varsayımlar altında; TFRS 16'nın finansal tablo ve oranlara etkisi ölçülmüş̧ür. Bu çerçevede, 2017 yılında Türkiye Muhasebe Standardı (TMS) 17 yerine TFRS 16 kullandıkları varsayılmıştır. İlgili hesaplar ve oranlar buna göre yeniden hesaplanmıştır. Böylece finansal tablolar ve finansal tablo kalemleri üzerindeki etkisini TMS 17 ve TFRS 16'ya göre görmek mümkün olmuştur.

Hesaplamalar ve analizler sonucunda dönem karında azalış; finansman gideri öncesi faaliyet kârı, esas faaliyet kârı, faiz gideri, toplam varlıklar ve toplam borçlarda artış tespit edilmiştir. Ayrıca sonuçlar ROA ve net kâr marjında azalış; borç-varlık ve faaliyet kâr marjında artış olduğunu göstermiştir.

TFRS 16'nın yürürlüğe girmesiyle birlikte, işletme kiralamalarıla ilgili hak ve borçlar bilançoda raporlanacaktır. Bu sayede finansal tabloların karşılaştırılabilirliği ve şeffaflĭ̆ı artacak, finansal oranlar daha önemli hale gelecektir. Bunun finansal tabloların adil sunumunun güçlendirilmesi üzerinde de önemli etkisi olacaktır.

Anahtar Kelimeler: TFRS 16, TMS 17, Faaliyet Kiralaması, Finansal Kiralama, Finansal Performans

\footnotetext{
${ }^{1}$ Bu çalşşma 30-31 Mayıs 2019 tarihleri arasında Piri Reis Üniversitesi'nde düzenlenen Global İşletme Araştırmaları Kongresi'nde (GİAK2019) bildiri olarak sunulmustur.

${ }^{2}$ İstanbul Üniversitesi İșletme Fakültesi, sari@istanbul.edu.tr, ORCID: 0000-0001-6675-3214

${ }^{3}$ İstanbul Üniversitesi İșletme Fakültesi, nevzat.gungor@istanbul.edu.tr, ORCID: 0000-0001-9883-1985
} 


\begin{abstract}
Over the years, the Financial Accounting Standards Board (FASB) and the International Accounting Standards Board (IASB) have made numerous changes to controversial leasing rules. The International Financial Reporting Standard (IFRS) 16 Financial Leasing Standard published by IASB has been implemented as of January 1, 2019 (In Turkey, this standard is published under the name of TFRS 16 by Public Oversight Accounting and Auditing Standarts Authority).

The purpose of this paper is to analyze the impact of the new leasing standard on the financial statements and ratios of the firms and industries represented in the BISST 100 indice under a variety of assumptions.
\end{abstract}

The financial statements and disclosures of the 63 manufacturing companies listed in BISST 100 are investigated. Under various assumptions; the effect of IFRS 16 on the financial statements and ratios is measured. In this context, it was assumed in 2017, companies used IFRS 16 instead of IAS 17. The related accounts and ratios were recalculated accordingly. Thus, it was possible to see the effect on the financial statements and financial statements items according to IAS 17 and IFRS 16.

As a result of the calculations and analysis, decrease in income for the period; and increase in operating income before financial income/expense, operating income, financial expenses, total assets and total labilities are determined. And also, the findings indicate there is a decrease in $R O A$ and net profit margin; increase in debt to asset and operating income margin.

With the adoption of IFRS 16, the rights and liabilities related to the operating leases will be reported on the balance sheet. In this way, the comparability will increase and financial ratios will become more significant. This will also have an impact on strengthening the fair presentation of financial statements.

Keywords: IFRS 16, IAS 17, Operational Lease, Financial Lease, Financial Performance

\title{
Giriş
}

Kiralama Türk Dil Kurumu sözlüğünde "Bir taşınır veya taşınmazın kullanım hakkının belli bir süre için ve belli bir kira karşılığında kiracıya verilmesi” olarak tanımlanmaktadır. Kiralama işlemleri, özellikle işletmeler için satın alınması zor olan yüksek meblağlı varlıkların kullanılabilmesi ve bu varlıkların yaratacağı ekonomik faydaların kiracı işletme tarafından elde edilebilmesini sağlayan bir alternatiftir. Bilanço dışı finansman yöntemleri arasında yer alan kiralama işlemleri ile kavramsal olarak bir varlığın kullanım hakkı kira ödemeleri karşılığında sahibi tarafından kullanıcıya devredilmektedir (Sipahi, 2004, s. 3). Ancak kiralama işlemleri sonucu kiracı açısından ortaya çıkan hak ve yükümlülüklerin bilanço dışı bırakılması işletmelerin varlıklarının ve kaynakları toplamlarının ne kadar gerçekçi olduğu sorusuna neden olmaktadır. Kiralama işlemlerinin muhasebeleştirilmesi ve raporlanması yıllardır akademik çevreler, standart koyucular, işletme yöneticileri ve finansal tablo kullanıcıları açısından tartışmalı bir konu olmuştur (Tai, 2013, s. 129). Faaliyet kiralamalarının 2019 yılından önce kiracının bilançosunda raporlanamamasının bilançoda raporlanan varlıklar ve yükümlülükler 
üzerinde önemli etkisi olduğu bilinmektedir (Altıntaş \& Türel, 2017, s. 131). Amerikan Sermaye Piyasası Kurulu (SEC) 2005 yılında Amerika Birleşik Devletleri (ABD)'ndeki halka açık şirketlerin bilanço dışı bıraktı̆̆ı kiralama işlemlerinin toplam tutarının yaklaşık 1,25 trilyon ABD doları olduğunu açıklamıştır.

$\mathrm{Bu}$ tartışmaları mümkün olduğunca giderebilmek amacıyla UMSK ve FMSK 2006 yılında kiralama işlemlerinin muhasebeleştirilmesi ve raporlanmasına ilişkin ortak bir proje başlatmışlardır. Önemli bir kısmı G4+1 grubu tarafından yürütülen projenin odak noktası bir yıldan uzun süreli ve iptal edilmez olan tüm kiralama işlemlerinin bilançoda raporlanmasıydı (Fülbier, Silva \& Pferdehirt, 2008, s. 122-123). 2009 yılında UMSK ve FMSK resmi olarak yayımladıkları bir doküman ile yapılan çalışmayı sunmuş ve yoruma açmışlardır. İlgili taraflardan gelen 780'den fazla yorum mektubu sonucunda 2010 yllinda taslak metin yayımlanmıştır (DiSalvio \& Dorata, 2014, s. 16-17). Taslak metinde tüm kiralama işlemlerinin bilançoda raporlanması gerektiği belirtilmekteydi ancak bu zorunluluk daha sonra değiştirilmiştir (Wong \& Joshi, 2015, s. 29). Yayınlanan taslakta kiralama işlemlerinin raporlanmasında "kullanım hakkı" modelinin uygulanması gerektiği üzerinde durulmaktaydı. "Kullanım hakkı" modeline göre kiracının varlı̆̆ı kullanmaktan doğan haklarının ve yükümlülüklerinin kiracının bilançosunda raporlanması gerekmekteydi (Lee, Paik \& Yoon, 2014, s. 46). Kiralama işlemlerine ilişkin çalışmaların tamamlanması sonucunda Uluslararası Muhasebe Standardı (UMS - IAS) 17'nin yerini alan Uluslararası Finansal Raporlama Standardı (UFRS - IFRS) 162016 yılının Ocak ayında yayımlanmıștır. UFRS 16 - Kiralamalar Standardı 31.12.2018 ve sonrasında başlayan hesap dönemleri için uygulamaya girmiş durumdadır. Türkiye'de UFRS 16 standardı TFRS 16 olarak KGK tarafından çevrilmiş, 16.4.2018 tarihli ve 29826 Sayılı Resmi Gazete'de yayımlanmış ve 31.12.2018 tarihinde başlayan hesap dönemlerinde uygulanmak üzere Türkiye'de yürürlüğe girmiştir. TFRS 16 Standardının yayınlanması ile 2006 yılından beri yürürlükte olan Türkiye Muhasebe Standardı (TMS) 17: Kiralama İşlemleri, TFRS Yorum 4: Bir Anlaşmanın Kiralama İşlemi İçerip İçermediğinin Belirlenmesi, TMS Yorum 15: Faaliyet Kiralamaları - Teşvikler ve TMS Yorum 27: Yasal Açıdan Kiralama Görünümündeki İşlemlerin Özünün Değerlendirilmesi yürürlükten kaldırılmıştır (TFRS 16, s. 31).

Çalışmanın ilk bölümünde gerek muhasebe uygulamaları gerekse finansal tablolara etkileri açısından konuya ilişkin daha önce yayınlanmış çalışmalar incelenecek, ikinci bölümde eski uygulama olan TMS 17 ve yeni uygulama olan TFRS 16'ya göre kiralama işlemlerinin muhasebeleştirilmesi ve raporlanmasındaki farklılıklar ele alınacaktır. Çalışmanın üçüncü bölümünde Borsa İstanbul (BİST)'da yer alan üretim işletmelerinin TFRS 16 standardını uygulamaları halinde finansal tablolarına olası etkileri değerlendirilecektir.

\section{Literatür İncelemesi}

Kiralama işlemlerinin muhasebeleştirilmesi, raporlanması ve finansal tablolar ile finansal oranlara etkisi üzerine yapılmış çalışmalar incelendiğinde çalışmaları iki grup olarak ele almak gerektiği görülmektedir. Bunlardan ilki kiralama işlemlerindeki değişikliklerin finansal tablolara ve finansal oranlara etkisi üzerinde duran, genellikle istatistiki analizlerden faydalanan 
çalışmalardır. Bu grup ta yer alan çalışmalar UFRS 16 ve TFRS 16 Standartlarının ortaya çıkmasından çok daha önceki yıllara kadar dayanmaktadır. İkinci grup çalı̧malar ise yeni kiralama standardının muhasebe uygulamalarını nasıl etkileyeceği ve finansal tablolarda kiralama işlemlerinin nasıl sunulması gerektiğini inceleyen, finansal tablo oranlarına etkisini inceleyen, uygulamada yol gösterici nitelikteki çalışmalardır.

Faaliyet kiralamalarının bilançoda varlık ve yükümlülükler arasında raporlanması konusunda ilk çalışma 1991 yılında Imhoff, Lipe ve Wright tarafından yapılmışıır. Çalışmada faaliyet kiralamalarının bilanço dışı bırakılmaması halinde varlıklara, yükümlülüklere ve işletme net kârına etkisi ayrıntılı olarak incelenmiştir. Fülbier, Silva ve Pferdehirt (2008) Almanya'da halka açı 90 işletmenin 2003 ve 2004 yılı verilerini kullanarak faaliyet kiralamalarının bilançoya alınmasının temel finansal oranlara etkilerini incelemişler ve tekstil ile perakendecilik sektöründe önemli etki yaratacağını tespit etmişlerdir. Hong Kong'da faaliyet gösteren iki restoran zinciri üzerinde çalışma yapan Tai (2013) faaliyet kiralamalarının bilançoda raporlanmasının aktif kârlılığı ve borç-özsermaye oranı üzerinde önemli etkisi olacağını belirlemiştir. Lee, Paik ve Yoon (2014), 1990-2011 yılları arasında Amerika Birleşik Devletleri (ABD)'nde faaliyet gösteren işletmelerin verilerini kullanarak faaliyet kiralamalarını bilançoda raporlamanın borçluluk yapısı, likidite ve finansal borç karşılama oranlarındaki etkisini incelemişlerdir. Çalışmada işletmeler üzerinde etkinin aynı olmadığı ve farklılıklar gösterdiğini tespit etmişlerdir. Paik, Smith, Lee ve Yoon (2015) bir diğer çalışmada lojistik regresyon analizi ile bilanço dışı kiralamaların etkisini inceleyerek faaliyet kiralamalarını bilançoda raporlamanın işletmelerin borçluluk oranlarını olumsuz etkileyeceği sonucuna ulaşmışlardır. Ericson ve Skarphagen (2015) faaliyet kiralamalarını bilançoda raporlamanın İsveç’te halka açı işletmelerin finansal oranlarına etkisini incelemişlerdir. 55 büyük ölçekli işletmenin incelendiği çalışmada yeni kiralama standardının borç-özsermaye oranı, aktif kârlılı̆̆ ve özsermaye kârlllığı oranlarında önemli etkisi olacağı belirlenmiştir. Benzer bir çalışma da Avustralya'da halka açık olan 170 işletmenin 2010 yılı verileri kullanılarak Wong ve Joshi (2015) tarafından yapılmıştır. Çalışmanın sonuçlarına göre yeni kiralama standardı borç-özsermaye, borç-varlık ve varlık kârlılı̆ı oranlarında istatistiksel olarak anlamlı etki yaratırken özsermaye kârlılı̆̆ı üzerindeki etkisi istatistiksel olarak anlamsızdır. Türkiye'de yapılan bir çalı̧̧ada ise Sarı, Altıntaş ve Taş (2016) perakendecilik sektöründe BİST’te yer alan işletmelerin finansal verilerini incelemişler ve TFRS 16 standardının uygulanması halinde borç-varlık oranında istatistiki açıdan anlamlı bir fark olmayacağını ancak borç-özsermaye oranında istatistiki açıdan anlamlı değişim yaşanacağını belirlemişlerdir. Acar, Temiz ve Aktaş (2017) çalışmalarında BİST’te ye alan perakende, taşımacllık, turizm ve telekomünikasyon sektörü işletmelerinin verilerini inceleyerek TFRS 16'nın uygulanması halinde kaldıraç oranlarının artacağı, kâr marjı, aktif kârlılığı ve özsermaye kârllığı oranlarında anlamlı değişim olacağını tespit etmişlerdir.

Serçemeli ve Öztürk (2016) çalışmalarında TFRS 16'nın yaratacağı değişiklikleri incelemişlerdir. Yazarlar çalışmaları sonucunda TFRS 16 'ile varlık ve yükümlülüklerin daha gerçekçi bir sunuma sahip olacağı, karşılaştırlabilirliğin artacağ ve IFRS 16 etkisinin sektörlere göre farkllık göstereceği sonucuna ulaşmışlardır. Öztürk 2016 yılında gerçekleştirdiği çalışmasında TFRS 16 ile UMS 17'yi karşılaştırmış buna ek olarak Almanya ve Türkiye'de hisse 
senetleri halka açık olan hava yolu şirketlerinin finansal durumuna etkisini incelemiştir. Çalışmada yazar yeni standardın muhasebenin şeffaflık, önemlilik ve gerçeğe uygun sunum ilkelerini karşılamada daha etkili olacağı sonucuna ulaşmıştır. Ayrıca yeni standardın etkisinin sektörel olarak değişiklik göstereceği ve faaliyet kiralamasına ağırlık veren işletmelerin daha çok etkileneceği sonucuna ulaşılmışıı. Aktaş, Kargın ve Arıcı 2017 yllında gerçekleştirdikleri çalışmalarında TFRS 16'yı hem muhasebeleştirme açısından hem de finansal tablolara ve oranlara etkisi açısından ele almışlardır. Yeni standart çerçevesinde muhasebe uygulamalarının nasıl olacağının açıklandığı çalışmada kiralama tutarlarının yüksek olduğu iki halka açık işletmenin finansal tabloları da incelenmiştir. Bulunan sonuçlara göre işletmelerin borçlanma oranlarında artış olmakta ve farklı sektörlerdeki şirketler farklı şekilde değişikliklerden etkilenmektedir. Aslan (2018) yılında yaptığı çalışmada TFRS 16 Standardı kapsamında kiracı tarafından kiralama işlemlerinin nasıl muhasebeleştirileceğini, nasıl bilançoda raporlanacağını incelemiştir. Çalışmanın sonuçlarına göre hava taşımacilığı, perakendecilik ve telekomünikasyon alanındaki işletmelerin yeni standarttan daha çok etkileneceği öngörülmektedir. Buna ek olarak yeni düzenlemenin faiz, vergi ve amortisman öncesi kâr (FVÖK - EBITDA), borçluluk oranı, amortisman ve finansman giderlerinde artı̧̧ yatacağı, cari oranı ise düşüreceği örnekler ile ortaya konmuştur. Demirci ve Kıvraklar (2018) ulusal ve uluslararası düzenlemeler çerçevesinde finansal kiralama işlemlerinin muhasebeleştirilmesine ilişkin çalışmalarında yeni kiralama standardının olası etkilerini de ele almışlardır. Finansal kiralama temelli olan bu çalışmada Muhasebe Sistemi Uygulama Genel Tebliği (MSUGT), Büyük ve Orta Boy İşletmeler İ çin Finansal Raporlama Standardı (BOBİ FRS), TMS 17 ve TFRS 16 açısından hem finansal hem faaliyet kiralamalarının finansal tablolarda nasıl sunulacağı üzerinde durulmuştur. Yazarlar sonuç olarak uygulamalar arasındaki farklılıkların giderilmesi gerektiği sonucuna ulaşmışlardır. Konuya ilişkin bir diğer çalışma Marşap ve Yanık (2018) tarafından yapılmıştır. Yazarlar çalışmalarında TFRS 16' ya geçişin muhasebe uygulamalarını ve finansal raporlamayı nasıl etkileyeceğini incelemişlerdir. Ulaştıkları sonuçlar kiracının finansal kaldıraç oranlarında değişiklikler olacağı ve hem kiracı hem de kiraya veren tarafın aynı varlık için amortisman gideri hesaplayıp raporlayacağıdır. TFRS 16'ya göre kiralama işlemlerinin muhasebeleştirilmesi ve ölçülmesine yönelik bir diğer çalışma Aksoy Hazır (2018) tarafından hazırlanmıştır. TMS 17 ve TFRS 16'nın karşılaştırıldığı çalışmada sonuç olarak eski ve yeni standardın başlıca farklılıkları ortaya konulmuştur.

\section{TFRS 16 ve TMS 17 Standartlarının Kiracı Açısından Karşılaştırılması}

Çalışmanın bu bölümünde TMS 17 ve TFRS 16 Standartları sınıflandırma, faaliyet kiralamalarında kiracı tarafından finansal tablolara alma ve ilk ölçüm, sonraki dönemlerde ölçme ve finansal tablolarda sunum açısından karşılaştırılacaktır.

\section{TFRS 16 ve TMS 17'de Kiralamalarının Sınıflandırma Açısından Karşılaştırılması}

Yürürlükten kalkmış olan TMS 17 standardında kiralama işlemleri faaliyet kiralaması ve finansal kiralama olarak ayrilmaktaydı. Aynı standartta hem faaliyet hem finansal kiralama işlemleri kiracı ve kiraya veren taraflar açısından ayrı ayrı ele alınmaktaydı. TMS 17 faaliyet kiralamasını finansal kiralamalar dışındaki kiralamalar olarak tanımlamaktaydı (TMS 17, p. 4, s.2). TFRS 16 Standardının EK A: Tanımlar kısmında ise faaliyet kiralamaları TMS 17'nin 
sınıflandırma kısmında yaptığı tanıma benzer bir şekilde "dayanak varlığın" mülkiyetinden kaynaklanan tüm risk ve getirilerin önemli ölçüde devredilmediği kiralama" olarak tanımlanmıştır (TFRS 16, Ek A, s.16).

TMS 17 Standardı finansal kiralamayı; bir varlığın mülkiyetine sahip olmaktan kaynaklanan risk ve yararların devredildiği sözleşme olarak tanımlamaktaydı. Sözleşme süresi sonunda mülkiyet devredilebilir ve devredilmeyebilirdi (TMS 17, p.4, s.2). Benzer tanım standardın sinıflandırma kısmında da yapılmaktaydı. TFRS 16 Standardında da finansal kiralama benzer şekilde; dayanak varlığın mülkiyetinden kaynaklanan tüm risk ve getirilerin önemli ölçüde devredildiği kiralamalar olarak tanımlanmıştır (TFRS 16, Ek A, s.15). Sınıflandırma açısından TMS 17 Standardı bir kiralama işleminin finansal kiralama olarak sinıflandırılabilmesi için standardın 10. ve 11. paragrafındaki kriterlerden tamamı ya da sadece birinin var olmasının yeterli olduğunu söylemekteydi. TFRS 16 Standardı sinıflandırma açısından incelendiğinde kiraya verenin kiralama işlemini finansal kiralama olarak sınıflandırabilmesi için TMS 17'de mevcut olan sekiz kriterin tamamının TFRS 16'nın 63. ve 64. paragraflarında yer aldığı görülmektedir.

Faaliyet kiralamalarının sinıflandırılmasında TMS 17 standardı sinıflandırma yapılırken bir varlığın mülkiyetine sahip olmaktan kaynaklanan risk ve yararların tamamının devredilmediği kiralamalar faaliyet kiralaması olarak sinıflandırılması gerektiği belirtilmekteydi (TMS 17, p.8, s.4). TFRS 16 incelendiğinde ise kiracı açısından faaliyet ve finansal kiralama farkını ortadan kalktığı görülmektedir. Kiracı açısından bir kiralama işleminin finansal tablolara alınmasında faaliyet kiralaması mı yoksa finansal kiralama mı olduğunun artık bir önemi yoktur. TFRS 16'nın 22. paragrafında kiracının, kiralamanın fiilen başladığı tarihte finansal tablolarına bir kullanım hakkı ve bir kira yükümlülüğü yansıtması gerektiği belirtilmektedir. Yeni standartta kiracının kiralama işlemini finansal tablolara almasına ilişkin istisnai durumlar da mevcuttur. $\mathrm{Bu}$ durumlar kısa vadeli kiralamalar ve dayanak varlığın düşük değerli olduğu kiralamalardır (TFRS 16, p.5, s.2). Kısa vadeli kiralama TFRS 16'da kiralamanın fiilen başladığı tarihten itibaren kiralama süresinin 12 aydan daha kısa olduğu ve satın alma opsiyonu olmayan kiralamalar olarak tanımlanmıştır (TFRS 16, Ek A, s.17).

\section{TFRS 16 ve TMS 17'de Kiralamaların Kiracı Açısından Finansal Tablolara Alınması ve illk Ölçümü}

TMS 17 Standardında faaliyet kiralamalarına ilişkin elde edilen varlık ve kiralama kaynaklı yükümlülüklerin bilançoda sunulması mümkün değildir. Bu durumda faaliyet kiralamasından kaynaklanan varlık ve yükümlülükleri için ilk ölçümün yapılması da anlamsız bir hale gelmekteydi. Eski standart faaliyet kiralamasında, yapılan kira ödemelerinin doğrusal (eşit) olarak kiralama süresi boyunca gider olarak muhasebeleştirilmesi gerektiği belirtmekteydi (TMS 17, p.33, s.8).

\footnotetext{
${ }^{4}$ Dayanak varlık TFRS 16 Standardında; "Kiralamaya konu olan ve kiraya verenin, kullanım hakkını kiracıya verdiği varlık" olarak tanımlanmıştır.
} 
TFRS 16 Standardı ise TMS 17’ye göre bu konuda büyük farklılıklar içermektedir. Öncelikle TFRS 16 Standardı kiracının, kiralamanın fiilen başladığı tarihte finansal tablolara bir kullanım hakkı varlığı ve bir kira yükümlüğü yansıtması gerektiğini belirtmektedir (TFRS 16, p.22, s.4). $\mathrm{Bu}$ ifade kiralama işlemi TMS 17'de yer alan faaliyet kiralaması ve finansal kiralama ayrımına bakılmaksızın, istisnai durumlar haricinde tüm kiralamaların bilanço varlıklarında ve yükümlülüklerinde raporlanacağı anlamına gelmektedir.

Gerçekleştirilen ve bilançoda raporlanacak olan kiralama işlemlerinde kullanım hakkı veren varlığın ilk ölçümü TFRS 16 Standardına göre kiralamanın fiilen başladığı tarihte kullanım hakkı varlığın maliyeti ile yapılmalıdır (TFRS 16, p.23, s.4). Kullanım hakkı veren varlığın maliyetini oluşturabilecek birden fazla unsur vardır. Bu unsurlar; kiralamanın fiilen başladığ tarihteki kira yükümlülüklerinin bugünkü değeri, kiralamanın fiilen başladığ 1 tarihten önceki kira ödemelerinden alınan tüm teşviklerin düşülmesi ile bulunan tutar, kiracının katlandığı başlangıç maliyetleri ve kiracının kullanım hakkı veren varlığı kullanıma hazır hale getirene kadar katlandığı maliyetler (varlığın sökülmesi, taşınması, restorasyonu, montajı, tadilatı gibi başlangıç maliyetleri) (TFRS 16, p.24, s.4). Kiracı kiralama işlemine ilişkin ilk ölçümü yaparken ödenmemiş kira ödemelerinin bugünkü değerini hesaplamalıdır. Bugünkü değer hesaplanırken kiralamadaki zımni faiz oranı kolaylıkla belirlenebiliyorsa bu oran kullanılmalıdır. Aksi halde kiracının alternatif borçlanma faiz oranı kullanılmalıdır (TFRS 16, p.27, s.5).

\section{TFRS 16 ve TMS 17'de Kiralamalarının Kiracı Açısından Sonraki Dönemlerde Ölçümü}

Yürürlükten kalkmış olan TMS 17 Standardında kiracının sonraki dönemlerde ölçüm yapması gerekmemekteydi. Bunun nedeni bilançoda değerleme yapılacak bir varlık raporlanmamış olmasıydı. TFRS 16 Standardında ise kiracı açısından faaliyet kiralaması ve finansal kiralama açısından bir farklılık olmaması nedeniyle faaliyet kiralaması sonucu bilançoda raporlanan varlık ve borçların sonraki dönemlerde yeniden ölçümü gerekmektedir.

TFRS 16 Standardında kiralama fiilen başladıktan sonra kiracı, kullanım hakkı varlığını maliyet yöntemi ile ölçmelidir (TFRS 16, p.29, s.5). Ancak bu durumun istisnaları bulunmaktadır. Kiracının gayrimenkulleri için TMS 40: Yatırım Amaçlı Gayrimenkuller Standardında yer alan gerçeğe uygun değer yöntemini kullanması halinde, kullanım hakkı veren varlık TMS 40'da yer alan gayrimenkul tanımını karşılıyorsa gerçeğe uygun değer yöntemi ile sonraki ölçümler yapılmalıdır. Bir diğer istisna ise kullanım hakkı veren varlığın TMS 16: Maddi Duran Varlıklar Standardında yer alan değerleme yöntemlerinin uygulandığı bir maddi duran varlık sınıfı ile ilişkili olmasıdır. Bu durumda kiracı kullanım hakkı veren varlık için yeniden değerleme yöntemini seçebilir (TFRS 16, p.34-35, s.5-6).

Kiracı tarafından kullanım hakkı varlığın sonraki ölçümlerinde dikkat edilmesi gereken bir diğer nokta da amortisman süresinin ne kadar olacağıdır. TFRS 16' da amortisman süresini belirlenirken kullanım hakkı veren varlığın yararlı ömrü veya kiralama süresi dikkate alınmaktadır. Eğer kiralama süresi sonunda dayanak varlığın mülkiyeti kiracıya devroluyorsa veya kiracı için satın alma opsiyonunu kullanma söz konusu ise varlık yararlı ömrünün sonuna kadar amortismana tabi tutulmalıdır. Diğer durumlarda kiracı varlığın yararlı ömrü veya kiralama süresinden kısa olanı kullanarak varlığı amortismana tabi tutar (TFRS 16, p.32, s.5). 
Kiracı faaliyet kiralaması dâhi yapıyor olsa kiralama işlemi sonucu ortaya çıkan kullanım hakkı varlığı ve kiralama yükümlülüklerini bilançosunda raporlamalıdır. İlerleyen dönemlerde kiracı kullanım hakkı varlığın ve kiralama yükümlülüklerinin ölçümünü yapmaya devam etmelidir. Kiralamanın fiilen başladığı tarihten sonra kiracı, kira yükümlülüğünü ölçerken; defter değerini, kira yükümlülüğündeki faizi yansıtacak şekilde arttırmalı, yapılan kira ödemelerini yansıtacak şekilde azaltmalı ve yeniden değerlendirmeleri, kiralamada yapılan değişiklikleri ya da revize edilmiş özü itibariyle sabit kira ödemelerini yansıtacak şekilde ölçmelidir (TFRS 16, p.36, s.6). Kiracı kira yükümlülüğüne ilişkin faiz giderini hesaplarken kullanması gereken faiz oranı kullanım hakkı varlığın bugünkü değeri hesaplanırken kullanılan iskonto oranı (zımni faiz oran1 $1^{5}$ veya kiracının alternatif borçlanma faiz oranı) veya revize edilmiş iskonto oranını kullanmalıdır (TFRS 16, p.37, s.6).

Kiracı tarafından revize edilmiş iskonto oranı kullanımını gerektiren durumlar TFRS 16' da açıklanmıştır. Standartta kiralamanın fiilen başladığı tarihten sonra kiracının, daha önce kiralama süresini belirlerken dikkate almadığı bir opsiyonu kullanacağından ya da daha önce kiralama süresini belirlerken dikkate aldığı bir opsiyonu kullanmayacağından makul ölçüde emin olup olmamasını etkileyen ve kiracının kontrolünde olan önemli bir olayın veya koşullarda önemli bir değişikliğin meydana gelmesi durumunda kiracının, kiralama süresini yeniden değerlendireceği belirtilmiştir. Bu duruma ek olarak kiracı, iptal edilemez kiralama süresinde değişiklik olması durumunda kiralama süresini revize etmelidir (TFRS 16, p.20-21, s.4). Bu iki durumun var olması halinde kiracı kira yükümlülüğünün yeniden ölçümünde revize edilmiş iskonto oranını kullanmalıdır.

\section{TFRS 16 ve TMS 17'de Kiralamaların Kiracı Açısından Finansal Tablolarda Sunumu}

Daha önce belirtildiği gibi TFRS 16 Standardında kiracı açısından faaliyet kiralaması ile finansal kiralamanın bir farkı bulunmamaktadır. Kiracı, kullanım hakkı veren varlıklarını bilançosunda varlık olarak sunmalıdır. Eğer kiracı kullanım hakkı veren varlıkları ayrı olarak sunmuyorsa kullanım hakkı varlıkları, bu varlıkların ilişkili olduğu dayanak varlıklara sahip olsaydı bu varlıkları sunacağı hesapta raporlamalıdır ya da bilançoda hangi varlıkların kullanım hakkı veren varlık olduğunu açıklamalıdır. Kiracı varlıklarda olduğu gibi bilançonun yükümlülüklerinde de kiralama işlemlerinden doğan yükümlülükleri ayrı olarak sunmalıdır. Ayrı olarak sunmuyorsa hangi yükümlülük hesaplarının kiralama yükümlülüğü içerdiğini açıklamalıdır (TFRS 16, p.47, s.7).

TMS 17 yürürlükteyken faaliyet kiralamalarında kiracılar sadece kira giderlerini kâr veya zarar ve diğer kapsamlı gelir tablosunda raporlamaktaydılar. Ancak TFRS 16 Standardında faaliyet kiralamalarında da finansal kiralamalarda olduğu gibi kullanım hakkı veren varlıktan kaynaklanan amortisman ve kira yükümlülügünden kaynaklanan faiz gideri raporlanması gerektiği belirtilmektedir. Standarda göre faiz gideri ve amortisman gideri birbirlerinde ayrı sunulmalıdır ve faiz gideri finansman maliyetlerinin içinde raporlanmalıdır (TFRS 16, p.49, s.7).

\footnotetext{
${ }^{5}$ Zımni faiz oranı TFRS 16 Standardında; “(a) Kira ödemeleri ve (b) taahhüt edilmiş kalıntı değerin bugünkü değerini, (i) dayanak varlığın gerçeğe uygun değeri ile (ii) kiraya verene ait her türlü başlangıçtaki doğrudan maliyetlerin toplamına eşitleyen faiz oranı olarak tanımlanmıştır.
} 
TFRS 16 Standardının etkilediği bir diğer finansal tablo da nakit akış tablosudur. Standarda göre kiracı, nakit akış tablosunda, kira yükümlülüğüne ilişkin anapara ödemelerini finansman faaliyetlerinde, faiz ödemelerini TMS 7: Nakit Akış Tabloları Standardı çerçevesinde ve kısa vadeli kira ödemeleri, düşük değerli varlıkların kiralamasına ilişkin ödemeler ile kira yükümlülüğünün ölçümüne dâhil edilmeyen kira ödemeleri işletme faaliyetleri bölümünde sunulmalıdır (TFRS 16, p.50, s.7-8).

TFRS 16 Standardına Göre Faaliyet Kiralaması İşlemlerinin Muhasebeleştirilmesine iliş̧kin Örnekler

Çalışmanın bu bölümünde TMS 17 ve TFRS 16 Standartlarına göre faaliyet kiralamalarında kiracı taraf tarafından yapılması gereken muhasebe kayıtları ve kiracının faaliyet kiralamalarını finansal tablolarında nasıl sunacağı incelenecektir.

Örnek 1: A İşletmesi yönetim faaliyetlerinde kullanmak amacıyla 5 adet servis aracını 1 Ocak 2018 tarihinde 3 yıllığına kiralamıştır. Toplam kiralama borcu 400.000 TL'dir (Yıllık kira ödemeleri 100.000 TL'dir). Kira ödemeleri yıllık olarak her yılın ilk günü eşit taksitler halinde yapılacaktır (ilk ödeme 1 Ocak 2018 tarihinde yapılacaktır). Kiralama sözleşmesindeki zımni faiz oranı \%12'dir. A İşletmesi kullanım hakkı veren varlıklar için eşit paylı amortisman yöntemi uygulayacaktır. Kiralama işlemi finansal kiralama koşullarını yerine getirmemektedir.

\section{TMS 17'ye Göre Kiralama İsleminin İlk Muhasebeleștirmesi}

Kiralama işleminin ilk taksiti kiralamanın gerçekleștiği gün ödenmiştir.

\begin{tabular}{l|l|c|c|}
\hline TARİH & HESAPLAR & BORÇ & ALACAK \\
\hline 1.1 .2018 & 180. GELECEK AYLARA AİT GİDERLER & 100.000 & \\
& 100. KASA & & 100.000 \\
\hline
\end{tabular}

\section{TFRS 16’ya Göre Kiralama İșleminin İlk Muhasebeleștirmesi ve Raporlanması}

TFRS 16 Standardına göre bir yıldan uzun süren bu kiralama işleminin hem kiracının varlıklarında hem de yükümlülüklerinde raporlanması gerekmektedir. Raporlama işleminden önce gelecekteki kira ödemlerinin zımni faiz oranı ile indirgemiş bugünkü değerinin hesaplanması gerekir.

Anüite Bugünkü Değer $=100.000 \mathrm{TL} *(\mathrm{ABDFF})^{\mathrm{I}: \% 12, \mathrm{n}: 3}=240.183 \mathrm{TL}$

Ödemelerin Bugünkü Değeri $=240.183 \mathrm{TL}+100.000 \mathrm{TL}=340.183 \mathrm{TL}$

Aşağıdaki tabloda faaliyet kiralaması işleminin geri ödeme tablosu sunulmuştur.

\begin{tabular}{|c|c|c|c|c|c|c|c|c|c|c|c|}
\hline TAKSIT & TARIH & $\begin{array}{c}\text { DÖNEM } \\
\text { BAŞI } \\
\text { TOPLAM } \\
\text { KIRALAMA } \\
\text { BORCU } \\
\text { (TL) }\end{array}$ & $\begin{array}{c}\text { DÖNEM } \\
\text { BAŞI } \\
\text { ANAPARA } \\
\text { BORCU } \\
\text { (TL) } \\
\end{array}$ & $\begin{array}{c}\text { DÖNEM } \\
\text { BAŞI FAIZ } \\
\text { BORCU } \\
\text { (TL) }\end{array}$ & $\begin{array}{l}\text { FAiZ } \\
\text { ORANI } \\
\text { (TL) }\end{array}$ & $\begin{array}{c}\text { TOPLAM } \\
\text { ÖDEME } \\
\text { (TL) }\end{array}$ & $\begin{array}{l}\text { ANAPARA } \\
\text { ÖDEMESI } \\
\text { (TL) }\end{array}$ & $\begin{array}{c}\text { FAiz } \\
\text { ÖDEMESi } \\
\text { (TL) }\end{array}$ & $\begin{array}{l}\text { DÖNEM } \\
\text { SONU } \\
\text { TOPLAM } \\
\text { KIRALAMA } \\
\text { BORCU } \\
\text { (TL) } \\
\end{array}$ & $\begin{array}{l}\text { DÖNEM } \\
\text { SONU } \\
\text { ANAPARA } \\
\text { BORCU } \\
\text { (TL) }\end{array}$ & $\begin{array}{c}\text { DÖNEM } \\
\text { SONU } \\
\text { FAIZ } \\
\text { BORCU } \\
\text { (TL) }\end{array}$ \\
\hline 1 & 1.01 .2018 & 400.000 & 340.183 & 59.817 & 0,12 & 100.000 & 100.000 & 0 & 300.000 & 240.183 & 59.817 \\
\hline 2 & 1.01.2019 & 300.000 & 240.183 & 59.817 & 0,12 & 100.000 & 71.178 & 28.822 & 200.000 & 169.005 & 30.995 \\
\hline 3 & 1.01 .2020 & 200.000 & 169.005 & 30.995 & 0,12 & 100.000 & 79.719 & 20.281 & 100.000 & 89.286 & 10.714 \\
\hline 4 & 1.01 .2021 & 100.000 & 89.286 & 10.714 & 0,12 & 100.000 & 89.286 & 10.714 & 0 & 0 & 0 \\
\hline
\end{tabular}


Aşağıdaki kayıtlarda kullanım hakkı veren varlığı ve bu kullanım hakkından kaynaklanan yükümlülüğün ilk muhasebeleştirilmesi gösterilmektedir.

\begin{tabular}{l|l|r|r}
\hline TARİH & HESAPLAR & BORÇ & ALACAK \\
\hline 1.1 .2018 & 260. HAKLAR & 340.183 & \\
& 260.01 KULLANIM HAKKI VARLIK & & \\
& 309. DİĞER MALİ BORÇLAR & & 100.000 \\
& 309.01 KİRALAMA BORÇLARI & & \\
& 409. DİĞER MALİ BORÇLAR & & 240.183 \\
& 409.01 KİRALAMA BORÇLARI & & \\
\hline
\end{tabular}

Kiralamanın gerçekleştiği tarihte ilk kira taksiti ödenmiştir. Bu ödeme faiz içermemektedir.

\begin{tabular}{l|l|c|c}
\hline TARİH & HESAPLAR & BORÇ & ALACAK \\
\hline 1.1 .2018 & $\begin{array}{l}\text { 309. DİGER MALİ BORÇLAR } \\
\text { 309.01 KİRALAMA BORÇLARI } \\
\text { 100.KASA }\end{array}$ & 100.000 & \\
& \multicolumn{1}{|l}{} & & 100.000 \\
\hline
\end{tabular}

TFRS 16’ya göre kiralama konusu olan varlığa ilişkin borçlar kiracı işletmenin bilançosunda aşağıdaki şekilde sunulmalıdır.

\begin{tabular}{|c|c|c|c|c|}
\hline VARLIKLAR & $\begin{array}{r}\text { A İŞ } \\
1.1 .20 \\
\text { BİLA }\end{array}$ & $\begin{array}{l}\text { ETMESİ } \\
8 \text { TARİHLİ } \\
\text { NÇO (TL) }\end{array}$ & & KAYNAKLAR \\
\hline 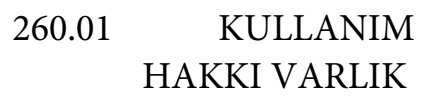 & 340.183 & $\begin{array}{l}409.01 \\
\text { BORÇLARI }\end{array}$ & KİRALAMA & 240.183 \\
\hline
\end{tabular}

\section{TFRS 17'ye Göre Kiralama İsleminin Sonraki Dönemlerde Ölçümü}

TFRS 17 Standardına göre kiracı faaliyet kiralamasına ilişkin ilerleyen dönemlerde bir işlem yapmayacaktır. Sadece yılsonunda 2018 başında peşin olarak ödediği 1.yıl kirasına ilişkin kira tutarını ilgili gider hesabına aktaracaktır.

\begin{tabular}{l|l|c|c}
\hline TARİH & HESAPLAR & BORÇ & ALACAK \\
\hline 31.12 .2018 & $\begin{array}{l}\text { 770. GENEL YÖNETIM GİDERLERİ } \\
\text { 770.01 KİRAAMA GIDERLERI } \\
\text { 180. GELECEK AYLARA AİT GİDERLER }\end{array}$ & 100.000 & \\
& \multicolumn{1}{|l}{} & & 100.000 \\
\hline
\end{tabular}

\section{TFRS 16’ya Göre Kiralama İșleminin Sonraki Dönemlerde Ölçümü}

TFRS 16 Standardına göre kiracının yılsonunda hem varlığı hem de yükümlülüğü yeniden ölçmesi gerekir. Bu ölçüm esnasında varlık maliyet değeri üzerinden ölçülürken döneme ilişkin faiz giderinin kiralama borcuna yansıtılarak arttırılması, yükümlülügün yapılan kira ödemesini yansıtacak şekilde azaltması gerekir.

Kullanım Hakkı Varlığın Amortisman Gideri = 340.183 TL / 4 Yıl = 85.046 TL

Kullanım hakkı varlığa ilişkin yıl sonu amortisman giderinin muhasebeleştirilmesi aşağıda sunulmuştur. 


\begin{tabular}{l|l|r|r}
\hline TARİH & HESAPLAR & BORÇ & ALACAK \\
\hline 31.12 .2018 & $\begin{array}{l}\text { 770. GENEL YÖNETIM GIDDERLERİ } \\
770.01 \text { AMORTISMAN GIDERİ } \\
\text { 268. BİRİKMİS AMORTİSMANLAR }\end{array}$ & 85.046 & \\
& \multicolumn{2}{|l}{} & \\
\hline
\end{tabular}

Kiralama işlemine ilişkin faiz giderinin muhasebeleştirilmesi aşağıda sunulmuştur. TFRS 16 Standardında da belirtildiği gibi yeniden ölçüm esnasında kiralama borcunun gerçekleşen faiz tutarı kadar arttırılması gerekmektedir. Bu nedenle 2018 yılı faiz gideri ayrı bir faiz borcu hesabı yerine kiralama borçları hesabına eklenmiştir.

\begin{tabular}{l|l|c|c}
\hline TARIH & HESAPLAR & BORÇ & ALACAK \\
\hline 31.12 .2018 & 780. FİNANSMAN GIDERLERİ & 28.822 & \\
& 780.01 KíRALAMA ISSLEMLERİ FAİZ GIDERİ & & \\
& 309. DİĞER MALİ BORÇLAR & & 28.822 \\
& 309.01 KİRALAMA BORÇLARI & & \\
\hline
\end{tabular}

1.1.2019 tarihinde ödenecek kiralama borcu 409'nolu hesaptan 309'nolu hesaba aktarılmalıdır.

\begin{tabular}{l|l|c|c}
\hline TARİH & HESAPLAR & BORÇ & ALACAK \\
\hline 31.12 .2018 & 409. DİĞER MALİ BORÇLAR & 71.178 & \\
& 409.01 KíRALAMA BORÇLARI & & \\
& 309. DİĞER MALİ BORÇLAR & & 71.178 \\
& 309.01 KİRALAMA BORÇLARI & & \\
\hline
\end{tabular}

Yılsonundaki işlemler tamamlandıktan sonra kiracının bilançosu aşağıdaki gibi olacaktır.

A İŞLETMESI

31.12.2018 TARIHLI

VARLIKLAR

BİLANÇO (TL)

KAYNAKLAR

260.01 KULLANIM

HAKKI VARLIK

268. (-) BİRIKKMISS

AMORTISMANLAR

\begin{tabular}{c|lcr} 
& & & \\
340.183 & 309.01 & KİRALAMA & 100.000 \\
$(85.046)$ & $\begin{array}{l}\text { BORÇLARI } \\
\text { 409.01 KIRALAMA BORÇLARI }\end{array}$ & 169.005
\end{tabular}

Kiracı açısından kiralama işlemine ilişkin hem TFRS 16 hem de TMS 17 standartlarına göre 2018 yılı gelir tablosu aşağıdaki gibidir.

\begin{tabular}{|c|c|c|}
\hline & $\begin{array}{c}\text { A İŞLETMESI GELÍR } \\
\text { TABLOSU } \\
2018 \text { YILI } \\
\text { (TL) } \\
\text { (TFRS 16) }\end{array}$ & $\begin{array}{c}\text { A İŞLETMESI GELİR } \\
\text { TABLOSU } \\
2018 \text { YILI } \\
\text { (TL) } \\
\text { (TMS 17) }\end{array}$ \\
\hline $\begin{array}{l}\text { GENEL YÖNETİM GİDERLERİ (AMORTİSMAN } \\
\text { GİDERİ) }\end{array}$ & $(85.046)$ & - \\
\hline FİNANSMAN GİDERLERİ (FAİZ GİDERİ) & (28.822) & - \\
\hline GENEL YÖNETİM GİDERLERİ (KİRA GİDERÍ) & - & $\overline{(100.000)}$ \\
\hline
\end{tabular}


Gelir tabloları karşılaştırıldığında görüldüğü gibi A İşletmesi TFRS 16’yı uyguladığında gelir tablosunda TMS 17’ye göre 13.868 TL daha fazla gider raporlayacaktır.

Örnek 2: Bayan giyim sektöründe mağazalar zincirine sahip olan B İşletmesi 1.1.2019 tarihinde bir alışveriş merkezinde 5 yıllığına bir işyeri kiralamıştır. Yıllık kira ödemeleri 300.000 TL'dir. Kira ödemeleri 1.1.2019'dan başlayarak her yılın başında yapılacaktır. Kiracının alternatif borçlanma faiz oranı 1.1.2019 tarihinde \% 18, 1.1.2020 tarihinde \% 22'dir. Kira ödemeleri her yıl Üretici Fiyat Endeksi (ÜFE) oranında arttırılacaktır. 1.1.2020 tarihinde ÜFE oranı \% 20'dir. B İşletmesi kullanım hakkı veren varlıklar için eşit paylı amortisman yöntemi uygulayacaktır. Kiralama işlemi finansal kiralama koşullarını yerine getirmemektedir.

\section{TFRS 16'ya Göre Kiralama İșleminin İlk Muhasebeleștirmesi ve Raporlanması}

Kiracı 1.1.2019 tarihinde kullanım hakkı varlığın ve kira yükümlülüklerinin bugünkü değerini belirlemelidir. Kullanım hakkı varlık ve kira yükümlülüğü belirlenirken sözleşme tarihindeki (1.1.2019) kira tutarları (300.000 TL) ve aynı tarihte kiracının alternatif borçlanma faiz oranı (\% 18) dikkate alınacaktır.

Anüite Bugünkü Değer $=300.000 \mathrm{TL} *(\mathrm{ABDFF})^{\mathrm{I}: \% 18, \mathrm{n}: 4}=807.019 \mathrm{TL}$

Ödemelerin Bugünkü Değeri = 807.019 TL + 300.000 TL = 1.107.019 TL

Aşağıdaki tabloda faaliyet kiralaması işleminin 2019 yılı başındaki geri ödeme tablosu sunulmuştur.

\begin{tabular}{|c|c|c|c|c|c|c|c|c|c|c|c|}
\hline TAKSIT & TARİH & $\begin{array}{c}\text { DÖNEM } \\
\text { BAŞI } \\
\text { TOPLAM } \\
\text { KİRALAMA } \\
\text { BORCU } \\
\text { (TL) }\end{array}$ & $\begin{array}{c}\text { DÖNEM BAŞI } \\
\text { ANAPARA } \\
\text { BORCU } \\
\text { (TL) }\end{array}$ & $\begin{array}{c}\text { DÖNEM } \\
\text { BAŞI FAİZ } \\
\text { BORCU } \\
\text { (TL) }\end{array}$ & $\begin{array}{c}\text { FAİZ } \\
\text { ORANI } \\
\text { (TL) }\end{array}$ & $\begin{array}{c}\text { TOPLAM } \\
\text { ÖDEME } \\
\text { (TL) }\end{array}$ & $\begin{array}{l}\text { ANAPARA } \\
\text { ÖDEMESİ } \\
\text { (TL) }\end{array}$ & $\begin{array}{c}\text { FAİZ } \\
\text { ÖDEMESİ } \\
\text { (TL) }\end{array}$ & $\begin{array}{c}\text { DÖNEM } \\
\text { SONU } \\
\text { TOPLAM } \\
\text { KIRALAMA } \\
\text { BORCU } \\
\text { (TL) }\end{array}$ & $\begin{array}{c}\text { DÖNEM } \\
\text { SONU } \\
\text { ANAPARA } \\
\text { BORCU } \\
\text { (TL) }\end{array}$ & $\begin{array}{l}\text { DÖNEM } \\
\text { SONU } \\
\text { FAİZ } \\
\text { BORCU } \\
\text { (TL) }\end{array}$ \\
\hline 1 & 1.01 .2019 & 1.500 .000 & 1.107 .019 & 392.981 & 0,18 & 300.000 & 300.000 & 0 & 1.200 .000 & 807.019 & 392.981 \\
\hline 2 & 1.01 .2020 & 1.200 .000 & 807.019 & 392.981 & 0,18 & 300.000 & 154.737 & 145.263 & 900.000 & 652.282 & 247.718 \\
\hline 3 & 1.01 .2021 & 900.000 & 652.282 & 247.718 & 0,18 & 300.000 & 182.589 & 117.411 & 600.000 & 469.693 & 130.307 \\
\hline 4 & 1.01 .2022 & 600.000 & 469.693 & 130.307 & 0,18 & 300.000 & 215.455 & 84.545 & 300.000 & 254.237 & 45.763 \\
\hline 5 & 1.01 .2023 & 300.000 & 254.237 & 45.763 & 0,18 & 300.000 & 254.237 & 45.763 & 0 & 0 & 0 \\
\hline
\end{tabular}

Aşağıdaki kayıtlarda kullanım hakkı veren varlığın ve bu kullanım hakkından kaynaklanan yükümlülüğün ilk muhasebeleştirilmesi gösterilmektedir.

\begin{tabular}{l|l|r|r}
\hline TARİH & HESAPLAR & BORÇ & ALACAK \\
\hline 1.1 .2019 & 260. HAKLAR & 1.107 .019 & \\
& 260.01 KULLANIM HAKKI VARLIK & & \\
& 309. DİĞER MALİ BORÇLAR & & 300.000 \\
& 309.01 KİRALAMA BORÇLARI & & \\
& 409. DİĞER MALİ BORÇLAR & & \\
& 409.01 KİRALAMA BORÇLARI & & \\
\hline
\end{tabular}


Kiralamanın gerçekleştiği tarihte ilk kira taksiti ödenmiştir. Bu ödeme faiz içermemektedir.

\begin{tabular}{l|l|c|c}
\hline TARİH & HESAPLAR & BORÇ & ALACAK \\
\hline 1.1 .2019 & $\begin{array}{l}\text { 309. DİGER MALİ BORÇLAR } \\
\text { 309.01 KíRALAMA BORÇLARI } \\
\text { 100. KASA }\end{array}$ & 300.000 & \\
& \multicolumn{1}{|l}{} & & 300.000 \\
\hline
\end{tabular}

\section{TFRS 16’ya Göre Kiralama İșleminin Sonraki Dönemlerde Ölçümü}

TFRS 16 Standardına göre kiracının yılsonunda hem varlığı hem de yükümlülüğü yeniden ölçmesi gerekir.

Kullanım Hakkı Varlığın Amortisman Gideri = 1.107.019 TL / 5 Yıl = 221.404 TL

Kullanım hakkı varlığa ilişkin yıl sonu amortisman giderinin muhasebeleştirilmesi aşağıda sunulmuştur.

\begin{tabular}{l|l|c|c}
\hline TARIH & HESAPLAR & BORÇ & ALACAK \\
\hline 31.12 .2019 & $\begin{array}{l}\text { 770. GENEL YÖNETIM GİDERLERİ } \\
\text { 770.01 AMORTISMAN GIDERİ } \\
\text { 268. BİRIKKMİŞ AMORTISMANLAR }\end{array}$ & 221.404 & \\
& \multicolumn{2}{|l}{} & \\
\hline
\end{tabular}

Kiralama işlemine ilişkin faiz giderinin muhasebeleştirilmesi aşağıda sunulmuştur.

\begin{tabular}{l|l|c|c}
\hline TARİH & HESAPLAR & BORÇ & ALACAK \\
\hline 31.12 .2019 & 780. FİNANSMAN GİDERLERİ FAİZ GİDERİ & 145.263 & \\
& 780.01 KİRALAMA İSLEMLERİ FAİZ GIDERİ & & \\
& 309. DİĞER MALİ BORÇLAR & & 145.263 \\
& 309.01 KİRALAMA BORÇLARI & & \\
\hline
\end{tabular}

1.1.2020 tarihinde ödenecek kiralama borcu 409'nolu hesaptan 309'nolu hesaba aktarılmalıdır.

\begin{tabular}{l|l|c|c}
\hline TARİH & HESAPLAR & BORÇ & ALACAK \\
\hline 31.12 .2019 & 409. DİĞER MALİ BORÇLAR & 154.737 & \\
& 409.01 KİRALAMA BORÇLARI & & \\
& 309. DİĞER MALİ BORÇLAR & & 154.737 \\
& 309.01 KİRALAMA BORÇLARI & & \\
\hline
\end{tabular}

2019 yılı sonunda kiracının bilanço tablosunda faaliyet kiralamasına ilişkin hesaplar aşağıdaki gibi raporlanacaktır.

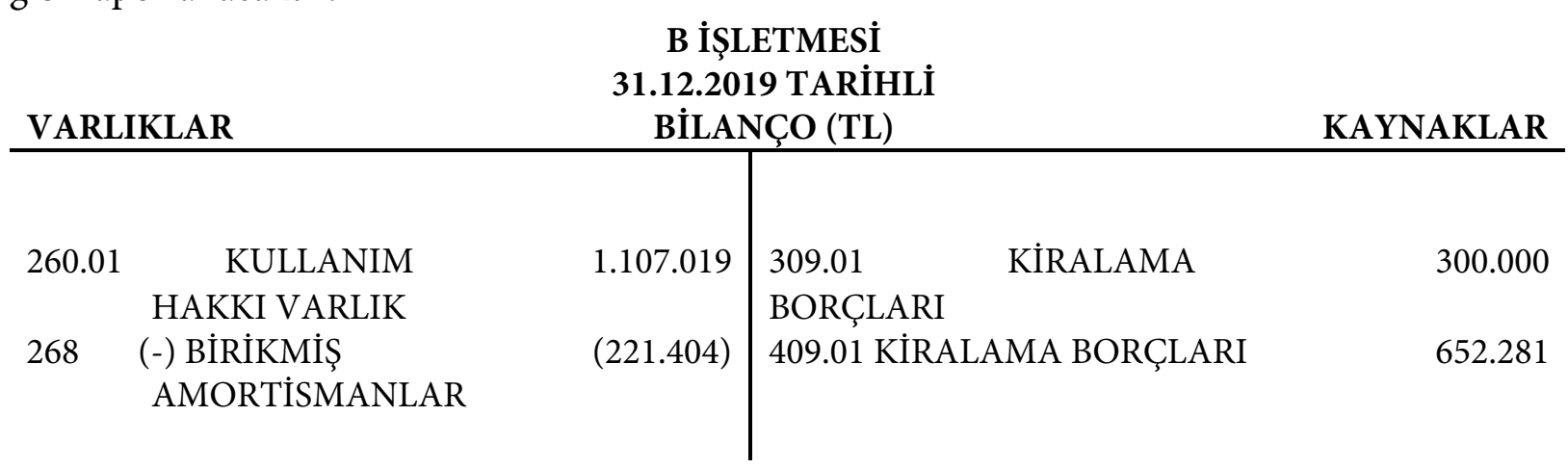

Kira sözleşmesinde kira ödemeleri sabit değildir ve ÜFE oranına göre her yıl artış gösterecektir. Ayrıca kiracının 2020 yılı başında alternatif borçlanma faiz oranı \% 22 olmuştur. Bu durumda 
kiracı işletmenin bilançosunda sunduğu kullanım hakkı varlığı ve faaliyet kiralaması borçlarını yeniden ölçmesi gerekmektedir.

ÜFE oranında arttırılmış kira taksitleri $=300.000 \mathrm{TL} * \% 1,20=360.000 \mathrm{TL}$

Aşağıdaki tabloda faaliyet kiralaması işleminin 2020 yılı başındaki revize edilmiş kira ödemeleri (360.000 TL) ve revize edilmiş iskonto oranı (\%22) kullanılarak hazırlanmış geri ödeme tablosu sunulmuştur.

\begin{tabular}{|c|c|c|c|c|c|c|c|c|c|c|c|}
\hline TAKSİT & TARİH & $\begin{array}{c}\text { DÖNEM } \\
\text { BAŞI } \\
\text { TOPLAM } \\
\text { KİRALAMA } \\
\text { BORCU } \\
\text { (TL) }\end{array}$ & $\begin{array}{c}\text { DÖNEM BAŞI } \\
\text { ANAPARA } \\
\text { BORCU } \\
\text { (TL) }\end{array}$ & $\begin{array}{l}\text { DÖNEM } \\
\text { BAŞI FAİZ } \\
\text { BORCU } \\
\text { (TL) }\end{array}$ & $\begin{array}{l}\text { FAİZ } \\
\text { ORANI } \\
\text { (TL) }\end{array}$ & $\begin{array}{c}\text { TOPLAM } \\
\text { ÖDEME } \\
\text { (TL) }\end{array}$ & $\begin{array}{l}\text { ANAPARA } \\
\text { ÖDEMESI } \\
\text { (TL) }\end{array}$ & $\begin{array}{c}\text { FAİZ } \\
\text { ÖDEMESİ } \\
\text { (TL) }\end{array}$ & $\begin{array}{c}\text { DÖNEM } \\
\text { SONU } \\
\text { TOPLAM } \\
\text { KİRALAMA } \\
\text { BORCU } \\
\text { (TL) }\end{array}$ & $\begin{array}{c}\text { DÖNEM } \\
\text { SONU } \\
\text { ANAPARA } \\
\text { BORCU } \\
\text { (TL) }\end{array}$ & $\begin{array}{c}\text { DÖNEM } \\
\text { SONU } \\
\text { FAİZ } \\
\text { BORCU } \\
\text { (TL) }\end{array}$ \\
\hline 1 & 1.01 .2020 & 1.440 .000 & 1.095 .207 & 344.793 & 0,22 & 360.000 & 360.000 & 0 & 1.080 .000 & 735.207 & 344.793 \\
\hline$\overline{2}$ & 1.01 .2021 & 1.080 .000 & 735.207 & 344.793 & 0,22 & 360.000 & 198.254 & 161.746 & 720.000 & 536.952 & 183.048 \\
\hline 3 & 1.01 .2022 & 720.000 & 536.952 & 183.048 & 0,22 & 360.000 & 241.870 & 118.130 & 360.000 & 295.082 & 64.918 \\
\hline 4 & 1.01 .2023 & 360.000 & 295.082 & 64.918 & 0,22 & 360.000 & 295.082 & 64.918 & 0 & 0 & 0 \\
\hline
\end{tabular}

31.12.2019 tarihinde bilançoda raporlanmış olan kira borcu 952.282 TL, 2020 yılı başında yapılan hesaplamalara göre kira borcu 1.095.207 TL'dir. Aradaki fark kadar kira borcu hesabının ve kullanım hakkı varlık hesabının arttırılması gerekir.

Kira Borcu Fark1 = 1.095.207 TL $-952.282 \mathrm{TL}=142.925 \mathrm{TL}$

\begin{tabular}{l|l|c|c}
\hline TARİH & HESAPLAR & BORÇ & ALACAK \\
\hline 1.1 .2020 & 260. HAKLAR & 142.925 & \\
& 260.01 KULLANIM HAKKI VARLIK & & \\
& 309. DİĞER MALİ BORÇLAR & & 60.000 \\
& 309.01 KİRALAMA BORÇLARI & & \\
& 409. DİĞER MALİ BORÇLAR & & 82.925 \\
& 409.01 KİRALAMA BORÇLARI & & \\
\hline
\end{tabular}

Kiracının 1.1.2020 tarihinde ikinci kira taksitini ödemesi gerekmektedir. Bu ödeme hem anapara hem faiz ödemesi içerecektir ancak faiz gideri 2019 yılı içinde raporlandığ için tekrar faiz gideri hesaplanıp raporlanmayacaktır.

\begin{tabular}{l|l|c|c}
\hline TARİH & HESAPLAR & BORÇ & ALACAK \\
\hline 1.1 .2020 & $\begin{array}{l}\text { 309. DİĞER MALI BORÇLAR } \\
\text { 309.01 KíRALAMA BORÇLARI } \\
\text { 100. KASA }\end{array}$ & 360.000 & \\
\hline
\end{tabular}

Revize edilmiş kira ödemeleri ve iskonto oranına göre B İşletmesi'nin 1.1.2020 tarihli bilanço aşağıdaki gibi olacaktır.

\section{B İŞLETMESI}

1.1.2020 TARİHLI

VARLIKLAR

BİLANÇO (TL)

KAYNAKLAR

\begin{tabular}{lll|ll}
260.01 & \multicolumn{1}{c}{ KULLANIM } & 1.249 .944 & 409.01 & KİRALAMA \\
HAKKI VARLIK & & (221.404) & & \\
BORÇLARI & & \\
(-) BİRIKMISS & AMORTISMANLAR & &
\end{tabular}

735.206

2020 yılı sonunda kullanım hakkı varlığa ilişkin amortisman giderinin raporlanması gerekir. 2020 yılı amortisman gideri aşağıdaki gibi hesaplanacaktır.

Amortismana Tabi Tutar $=1.249 .944 \mathrm{TL}-221.404 \mathrm{TL}=1.028 .540 \mathrm{TL}$ 
Yillık Amortisman Gideri = 1.028.540 TL / 4 Y1l = 257.135 TL

\begin{tabular}{l|l|c|c}
\hline TARİH & HESAPLAR & BORÇ & ALACAK \\
\hline 31.12 .2020 & $\begin{array}{l}\text { 770. GENEL YÖNETIM GIDERLERİ } \\
\text { 770.01 AMORTİSMAN GİDERİ } \\
\text { 268. BİRIKKMİ̧ AMORTISMANLAR }\end{array}$ & 257.135 & \\
& & & 257.135 \\
\hline
\end{tabular}

Yılsonunda yapılması gereken bir diğer işlem kira borcuna ilişkin 2020 yılı faiz giderinin raporlanmasidir.

\begin{tabular}{l|l|c|c}
\hline TARİH & HESAPLAR & BORÇ & ALACAK \\
\hline 31.12 .2020 & 780. FINANSMAN GIDERLERİ & 161.746 & \\
& $\begin{array}{l}\text { 780.01 KİRALAMA İŞLEMLERI FAİZ GIDERİ } \\
\text { 309. DİĞER MALİ BORÇLAR } \\
\end{array}$ & & \\
& 309.01 KİRALAMA BORÇLARI & & 161.746 \\
\hline
\end{tabular}

1.1.2021 tarihinde ödenecek kiralama borcu 409'nolu hesaptan 309'nolu hesaba aktarılmalıdır.

\begin{tabular}{l|l|c|c}
\hline TARİH & HESAPLAR & BORÇ & ALACAK \\
\hline 31.12 .2020 & 409. DİĞER MALİ BORÇLAR & 198.254 & \\
& 409.01 KİRALAMA BORÇLARI & & \\
& 309. DİĞER MALİ BORÇLAR & & 198.254 \\
& 309.01 KIRALAMA BORÇLARI & & \\
\hline
\end{tabular}

2020 yılı sonunda kiracının bilançosunda faaliyet kiralamasına ilişkin hesaplar aşağıdaki gibi raporlanacaktır.

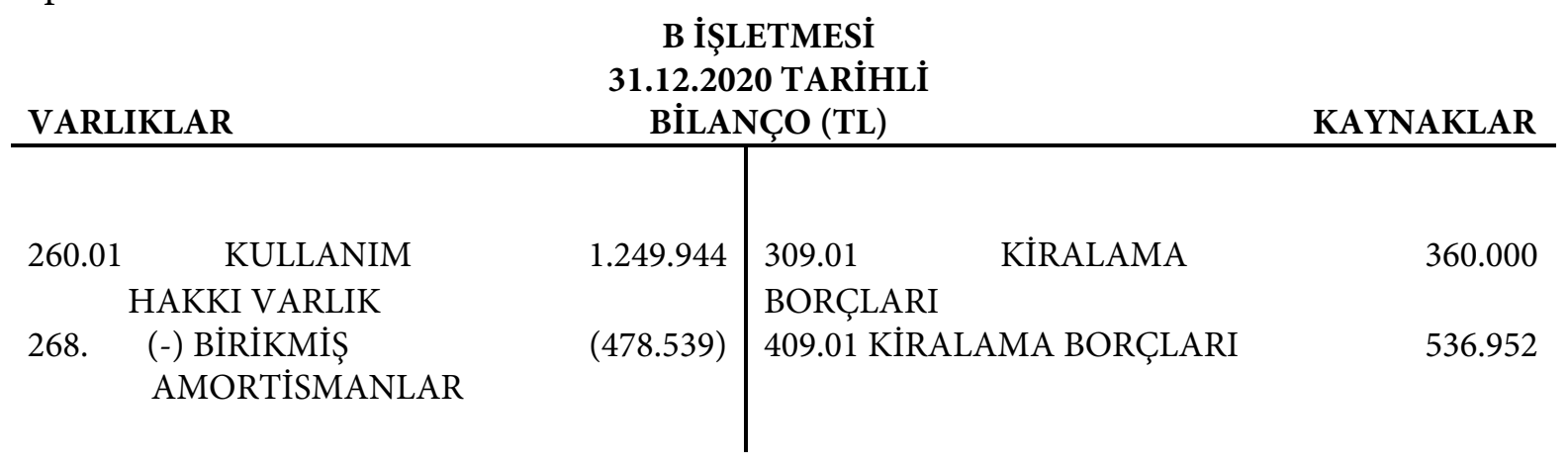

Kiracı işletme 2020 yılı başında olduğu gibi kira sözleşmesi bitene kadar kira tutarlarındaki artış ve alternatif borçlanma faiz oranındaki değişimi dikkate alarak kullanım hakkı varlığı ve kiralama borcunu yeniden ölçmelidir.

Yukarıdaki örneklerde de görüldüğ̈̈ gibi kiracı açısından TMS 17 ve TFRS 16 standartları arasında muhasebeleştirme ve raporlama açısından büyük farklılıklar bulunmaktadır. TMS 17'den farklı olarak yeni standartta kiracı işletmenin bilançosunun varlıklarında raporlayacağı bir varlığı ve yükümlülüklerde raporlayacağı bir borcu ortaya çıkmaktadır. Bu durum gelir tablosunda raporlanacak hesapları ve tutarları da değiştirmektedir. Dikkat edilmesi gereken bir diğer nokta ise kira sözleşmesinde ortaya çıkabilecek değişiklikler sonucu kullanım hakkı varlık ve kira borcuna ilişkin tutarların revize edilmesi gerekliliğidir.

\section{TMS 17'den TFRS 16'ya Geçisin Etkileri: BiST 100 Şirketleri Üzerine Bir İnceleme}

Çalışmanın bu bölümünde TMS 17'den TFRS 16'ya geçişin işletmelerin finansal tabloları ve finansal oranları üzerindeki olası etkileri incelenecektir. Bu çerçevede Ekim 2018 itibariyle BİST 100 endeksinde yer alan şirketlerin finansal verileri incelenmiştir. BİST 100 endeksinde bulunan şirketlerden mali kuruluşlar çalışmanın kapsamı dışında bırakılmış ve geriye kalan 63 şirketin 2017 yılına ait finansal tabloları ve dipnotları incelenmiştir. 
Bu çalışma çerçevesinde ilk olarak TFRS 16 standardı uygulandığı varsayımı altında, TFRS 16 Standardının şirketlerin bilançosu ve gelir tablosuna etkisi incelenecektir. Çalışmanın devamında TFRS 16'nın, örneklemi oluşturan şirketlerin bir bütün olarak başlıca finansal tablo kalemlerine ve finansal oranlarına etkisi değerlendirilecektir. Son olarak TFRS 16'nin çalışmada yer alan şirketlerin finansal tablo kalemlerine ve finansal oranlarına etkisi sektörel açıdan da analiz edilecektir.

\section{Çalışmanın Veri Seti}

TFRS 16 standardına göre işletmeler faaliyet kiralamalarına ilişkin ortaya çıkan varlık ve yükümlülüklerini bilançosunda raporlamalıdır. Bu raporlamanın etkisinin hesaplanabilmesi için finansal tablo dipnotlarında gelecek yıllara ait iptal edilemez faaliyet kiralamalarının tutarlarının ve vadelerinin sunulması gerekmektedir. Bunun yanı sıra TFRS 16'nın etkisinin ölçülebilmesi için şirketlerin finansal tablo dipnotlarında 2017 yılına ait faaliyet kiralaması giderleri de raporlanmalıdır. Çalışmanın evreni olan 63 şirketin tamamının finansal tablo dipnotları incelenmiş ve sadece 16 şirketin finansal tablo dipnotlarında gelecek y1llara ait iptal edilemez faaliyet kiralamaları bilgilerini ve 2017 yılına ait kira giderlerini sundukları görülmüştür. Bu şirketler ve faaliyet gösterdikleri sektörler aşağıdaki tabloda sunulmaktadır.

\section{Tablo 1. Çalışmanın Örneklemi}

\begin{tabular}{|c|c|c|}
\hline Şirket & Sektör & Faaliyet Konusu \\
\hline $\begin{array}{l}\text { ANEL Elektrik Proje Taahhüt ve } \\
\text { Ticaret A.Ş. }\end{array}$ & İnşaat ve Bayındırlık & İnşaat ve Bayındırlık İşleri \\
\hline Arçelik A.Ş. & İmalat Sanayii & $\begin{array}{l}\text { Metal Eşya, Makine ve Gereç } \\
\text { Yapım }\end{array}$ \\
\hline Coca-Cola İçecek A.Ş. & İmalat Sanayii & Gida, İçki ve Tütün \\
\hline Deva Holding & İmalat Sanayii & $\begin{array}{l}\text { Kimya, Petrol Kauçuk ve Plastil } \\
\text { Ürünler }\end{array}$ \\
\hline $\begin{array}{l}\text { Doğtaş Kelebek Mobilya Sanayi ve } \\
\text { Ticaret A.Ş. }\end{array}$ & İmalat Sanayii & Orman Ürünleri ve Mobilya \\
\hline Doğuş Otomotiv & $\begin{array}{l}\text { Toptan ve Perakende Ticaret, Otel ve } \\
\text { Lokantalar }\end{array}$ & Toptan Ticaret \\
\hline ENKA & İnşaat ve Bayındırlık & İnşaat ve Bayındırlık İşleri \\
\hline Mavi Giyim Sanayi ve Ticaret A.Ş. & $\begin{array}{l}\text { Toptan ve Perakende Ticaret, Otel Ve } \\
\text { Lokantalar }\end{array}$ & Perakende Ticaret \\
\hline Migros Ticaret A.Ş. & $\begin{array}{l}\text { Toptan ve Perakende Ticaret, Otel ve } \\
\text { Lokantalar }\end{array}$ & Perakende Ticaret \\
\hline MLP Sağlık Hizmetleri A.Ş. & $\begin{array}{l}\text { Eğitim, Sağlık, Spor ve Diğer Sosyal } \\
\text { Hizmetler }\end{array}$ & İnsan Sağlığı ve Sosyal Hizmetle \\
\hline Netaş Telekomünikasyon A.Ş. & Teknoloji & Bilişim \\
\hline Pegasus Hava Taşımacılığı A.Ş. & Ulaştırma, Haberleşme ve Depolama & Ulaştırma \\
\hline Turkcell İletişim Hizmetleri A.Ş. & Ulaştırma, Haberleşme ve Depolama & Haberleşme \\
\hline Türk Hava Yolları A.O. & Ulaştırma, Haberleşme ve Depolama & Ulaştırma \\
\hline Türk Telekomünikasyon A.Ş. & Ulaştırma, Haberleşme ve Depolama & Haberleşme \\
\hline Ülker Bisküvi Sanayi A.Ş. & İmalat Sanayii & Gida, İçki ve Tütün \\
\hline
\end{tabular}

\section{TFRS 16’nin Etkisinin Ölçülme Yöntemi ve Gerekli Varsayımlar}

TFRS 16'nin, örneklemi oluşturan şirketlere etkisinin ölçülmesinde Imhoff, Lipe ve Wright tarafından 1991 yılında geliştirilen "Kiralamaları Aktifleştirme Yöntemi (Lease Capitalization Method)" kullanılmıştır. Bu yöntem akademik çalışmalarda sıklıkla kullanılan (Beattie, vd. (1998), (Bennet ve Brandbury (2003), Duke vd. (2009), Singh (2010 ve 2011), Wong ve Joshi (2015), Sarı vd. (2016)) ve kabul görmüş bir yöntemdir. 
Bu yöntemin uygulanmasında ilk olarak örneklemi oluşturan şirketlerin 2017 yılı finansal tablo dipnotları incelenerek 1.1.2017 tarihindeki iptal edilemez faaliyet kiralaması tutarları ve vadeleri belirlenmiştir. Vadelerin genel olarak 1 yıldan az, 1-5 yıl arası ve 5 yıldan fazla olarak sınıflandırıldığı tespit edilmiştir. Faaliyet kiralamasına ilişkin finansal veriler kullanılarak şirketlerin TFRS 16 standardını 2017 yılında kullanmaları halinde varlıklarda ve yükümlülüklerde raporlanması gereken kullanım hakkı varlık ve kiralama borçları tutarları hesaplanacaktır. Buna ek olarak finansal tablo dipnotlarından örneklemi oluşturan işletmelerin 2017 yılında gelir tablosunda raporladıkları kira giderleri tespit edilmiştir. Kira giderlerinin tespit edilmesinin nedeni, TFRS 16 standardı kullanılması durumunda bu kira giderlerinin olmayacağı ve bu durumun gelir tablosunu etkileyeceği varsayımıdır.

TFRS 16'nın etkisinin ölçümünde varlık ve yükümlülük olarak bilançosunda raporlanacak tutarların, gelir tablosunda aktifleştirilen kiralama işlemlerinden kaynaklanan yıllık amortisman gideri ve faiz gideri tutarlarının hesaplanması gerekmektedir. Bu hesaplamaların yapılabilmesi için bazı varsayımların kullanılmalıdır. Kullanılan varsayımlar aşağıdaki gibidir:

- Yükümlülüklerde kısa dönem ve uzun dönem ayrımı yapılmamıştır.

- İskonto oranı olarak 10 yıl vadeli devlet tahvillerinin faiz oranı kullanılmıştır. İskonto oranı \% 11,31'dir.

- Faaliyet kiralamalarının 2017 yılı gelir tablosuna etkisinin ölçülebilmesi için faaliyet kiralamalarının 1.1.2017 tarihindeki bugünkü değerleri hesaplanmıştır.

- Faaliyet kiralamalarından kaynaklanan ödemelerin yılsonunda olduğu kabul edilmiştir. $\mathrm{Bu}$ durumda faaliyet kiralamasına ilişkin kiralama borçlarının faizinin de 31.12.2017 tarihinde ödendiği kabul edilmiştir.

- Şirketler faaliyet kiralamasına ilişkin vade bilgilerini 1 yıldan az, 1-5 yıl arası ve 5 yıldan fazla olarak sunmaktadır. İskonto oranı olarak 10 yıl vadeli devlet tahvilleri dikkate alındığg için 5 yıldan uzun kiralamaların da en fazla 10 yıla kadar süreceği kabul edilmiştir.

- 1-5 yıl ve 5-10 yıl arası olan kiralamalarda her yıl eşit kira ödemesi olacağı kabul edilmiştir. Bu durumda 1-5 yıl arası toplam olarak raporlanan kira ödemesi tutarı 4'e, 5-10 yıl arası toplam olarak raporlanan kira ödemesi tutarı ise 5'e bölünerek yıllık ödenmesi gereken faaliyet kiralaması tutarları hesaplanmıştır.

- Amortisman hesaplamasında kullanım hakkı varlı̆̆ın faydalı ömrü gerekmektedir. İskonto süresi ve en uzun kiralama vadesi 10 yıl kabul edildiği için faydalı ömür de 10 yıl kabul edilmiştir.

- Amortisman yöntemi olarak eşit paylı (doğrusal) amortisman yöntemi kullanılmıştır.

- Kiralama süresi sonunda kullanım hakkı varlığın ve kiralama borçlarının defter değerlerinin sıfır olacağı kabul edilmiştir.

- TFRS 16 standardına göre hesaplamalar yapılırken 2017 yılına ait faaliyet kiralaması giderleri gelir tablosunda dikkate alınmamıştır. 


\section{TFRS 16'nin Etkisinin BiST 100 Üzerinde Ölçülmesi}

Başlangıçta örneklemi oluşturan 16 şirketin finansal tablo kalemleri ve faaliyet kiralaması verileri tek bir şirket gibi dikkate alınmıştır. Şirketlerin finansal tablo dipnotlarından elde edilen iptal edilemez faaliyet kiralamalarının vadelerine ilişkin bilgiler aşağıdaki tabloda sunulmuştur.

Tablo 2. Çalışmada Yer Alan Şirketlerin Faaliyet Kiralaması Bilgileri

\begin{tabular}{|l|c|}
\hline Vade & Kira Tutar1 \\
\hline 1 yildan az & $6.387 .646 .897 \mathrm{TL}$ \\
\hline $1-5$ y1l aras1 & $19.440 .817 .271 \mathrm{TL}$ \\
\hline 5 ylldan fazla & $17.892 .219 .976 \mathrm{TL}$ \\
\hline Toplam & $\mathbf{4 3 . 7 2 0 . 6 8 4 . 1 4 4} \mathrm{TL}$ \\
\hline
\end{tabular}

Varsayımlarda da belirtildiği gibi 1. yılın kira tutarı 2017 yılı sonunda ödenecektir. 1-5 yıl arası olan toplam tutar 4'e bölünmüş ve 2.,3.,4. ve 5. yıllarda ödenmesi gereken kira tutarı belirlenmiştir. 5 yıldan fazla olan kiralamalarda toplam tutar 5'e bölünerek gelecek 5-10 yıl arası ödenmesi gereken kira tutarı hesaplanmıştır.

Bir sonraki adımda iskonto oranı kullanılarak gelecek 10 yıla ait kira ödemelerinin bugünkü değerleri, henüz gerçekleşmemiş faiz gideri ve her yıl ödenecek anapara ile faiz tutarları hesaplanmıştır. Söz konusu hesaplamaları içeren geri ödeme tablosu aşağıda sunulmuştur.

Tablo 3. Çalışmada Yer Alan Şirketlerin Faaliyet Kiralamalarına İlişkin Geri Ödeme Tablosu

\begin{tabular}{|c|c|c|c|c|c|c|c|}
\hline & $\begin{array}{c}\text { DÖNEM BAŞI } \\
\text { TOPLAM } \\
\text { KİRALAMA } \\
\text { BORCU } \\
\text { YIL }\end{array}$ & $\begin{array}{c}\text { DÖNEM BAŞI } \\
\text { ANAPARA } \\
\text { BORCU }\end{array}$ & $\begin{array}{c}\text { DÖNEM BAŞI } \\
\text { FAİZ BORCU } \\
(\mathrm{TL})\end{array}$ & $\begin{array}{c}\text { FAİZ } \\
\text { ORANI } \\
(\%)\end{array}$ & $\begin{array}{c}\text { TOPLAM } \\
\text { ÖDEME } \\
(\mathrm{TL})\end{array}$ & $\begin{array}{c}\text { ANAPARA } \\
\text { ÖDEMESI } \\
\text { (TL) }\end{array}$ & $\begin{array}{c}\text { FAİZ ÖDEMESI } \\
(\mathrm{TL})\end{array}$ \\
\hline 1 & 43.720 .684 .144 & 26.875 .912 .306 & 16.844 .771 .838 & 11,31 & 6.387 .646 .897 & 3.347 .981 .215 & 3.039 .665 .682 \\
\hline 2 & 37.333 .037 .247 & 23.527 .931 .091 & 13.805 .106 .156 & 11,31 & 4.860 .204 .318 & 2.199 .195 .311 & 2.661 .009 .006 \\
\hline 3 & 32.472 .832 .929 & 21.328 .735 .780 & 11.144 .097 .149 & 11,31 & 4.860 .204 .318 & 2.447 .924 .301 & 2.412 .280 .017 \\
\hline 4 & 27.612 .628 .612 & 18.880 .811 .479 & 8.731 .817 .133 & 11,31 & 4.860 .204 .318 & 2.724 .784 .539 & 2.135 .419 .778 \\
\hline 5 & 22.752 .424 .294 & 16.156 .026 .939 & 6.596 .397 .354 & 11,31 & 4.860 .204 .318 & 3.032 .957 .671 & 1.827 .246 .647 \\
\hline 6 & 17.892 .219 .976 & 13.123 .069 .268 & 4.769 .150 .708 & 11,31 & 3.578 .443 .995 & 2.094 .224 .861 & 1.484 .219 .134 \\
\hline 7 & 14.313 .775 .981 & 11.028 .844 .407 & 3.284 .931 .573 & 11,31 & 3.578 .443 .995 & 2.331 .081 .693 & 1.247 .362 .302 \\
\hline 8 & 10.735 .331 .986 & 8.697 .762 .715 & 2.037 .569 .271 & 11,31 & 3.578 .443 .995 & 2.594 .727 .032 & 983.716 .963 \\
\hline 9 & 7.156 .887 .990 & 6.103 .035 .683 & 1.053 .852 .308 & 11,31 & 3.578 .443 .995 & 2.888 .190 .659 & 690.253 .336 \\
\hline 10 & 3.578 .443 .995 & 3.214 .845 .023 & 363.598 .972 & 11,31 & 3.578 .443 .995 & 3.214 .845 .023 & 363.598 .972 \\
\hline Toplam & & & & & $\mathbf{4 3 . 7 2 0 . 6 8 4 . 1 4 4}$ & $\mathbf{2 6 . 8 7 5 . 9 1 2 . 3 0 6}$ & $\mathbf{1 6 . 8 4 4 . 7 7 1 . 8 3 8}$ \\
\hline
\end{tabular}

Tablo 3 incelendiğinde anapara ödemeleri toplam tutarının 26.875.912.306 TL olduğu görülmektedir. $\mathrm{Bu}$ tutar gelecekteki faaliyet kiralaması ödemelerinin bilançoda varlık ve yükümlülük olarak raporlanması gereken bugünkü değeridir. Örneklemi oluşturan şirketler için tek bir bilanço oluşturulması halinde bu tabloda kullanım hakkı varlık ve kiralama borçlarının aşağıdaki gibi raporlanması gerekirdi. 
Bilançoda raporlanan kullanım hakkı varlık için 2017 yılında amortisman gideri raporlanması gerekmektedir. Daha önce belirtildiği gibi faydalı ömür 10 yıl, amortisman yöntemi ise eşit paylı amortisman yöntemi olarak belirlenmiştir. Bu durumda 2017 yllına ait amortisman gideri aşağıdaki gibi hesaplanacaktır.

2017 yılı amortisman gideri $=26.875 .912 .306 \mathrm{TL} / 10 \mathrm{yll} \cong 2.687 .591 .231 \mathrm{TL}$

Faaliyet kiralamasına ilişkin borçların yükümlülüklerde raporlanması durumunda bu borca ilişkin faiz gideri raporlanması gerekir. 2017 yılına ait faiz gideri 1.1.2017 tarihindeki anapara borcu ile faiz oranının çarpılması ile hesaplanır. Tabloda 3.039.665.682 TL olarak sunulan tutarın hesaplanması aşağıdaki gibidir.

2017 yll faiz gideri $=26.875 .912 .306 \mathrm{TL} x \% 11,31 \cong 3.039 .665 .682 \mathrm{TL}$

Faaliyet kiralamalarını aktifleştirmenin 31.12.2017 tarihli bilançosu ve 2017 yılı gelir tablosuna etkisi aşağıda sunulmuştur.

$\underline{\text { Varlıklar }}$

Çalışmada Yer Alan Şirketlerin 31.12.2017 Tarihli Bilançosu (TL)

\begin{tabular}{ll|lr}
\hline Kullanım Hakkı Varlık & 26.875 .912 .306 & Kiralama Borçları & Kaynaklar \\
Birikmiş & $(2.687 .591 .231)$ & & \\
Amortismanlar & & & \\
& &
\end{tabular}

\begin{tabular}{|l|}
\hline \multicolumn{2}{|c|}{$\begin{array}{c}\text { Çalışmada Yer Alan Şirketlerin } \\
2017 \text { Ylı Gelir Tablosu (TL) }\end{array}$} \\
\hline $\begin{array}{l}\text { Faaliyet Giderleri } \\
\text { Amortisman Gideri } \\
\text { Finansman Giderleri } \\
\text { Faiz Gideri }\end{array}$ \\
\hline
\end{tabular}


Bilançolar incelendiğinde görüldüğü gibi TFRS 16'nın 2017 yılında uygulanıyor olması halinde TMS 17’ye göre şirketlerin 1.1.2017 tarihinde toplam olarak yaklaşık 26,88 milyar TL daha fazla varlık ve yükümlülük raporlamaları gerekmektedir. Ayrıca yukarıda yer alan gelir tablosunda şirketlerin TMS 17 kapsamında raporlayamayacağı yaklaşık 2,69 milyar TL amortisman gideri ve 3,03 milyar TL faiz gideri raporlanmaktadır. Gelir tablosunda raporlanan tutarlar 2017 yılında TFRS 16 uygulanıyor olsaydı çalışmada yer alan şirketlerin amortisman giderleri ve faiz giderlerindeki artışı ifade etmektedir. Varsayımlarda belirtildiği üzere; 2017 yılına ait 5.316.396.591 TL tutarındaki faaliyet kiralaması gideri 0 TL olarak kabul edilmiştir.

Çalışmanın devamında 16 şirketin başlıca finansal tablo kalemlerinin TMS 17 ve TFRS 16 uygulanması durumunda tutarları ve değişimleri aşağıdaki tabloda sunulmuştur.

Tablo 4. TMS 17 ve TFRS 16'ya Göre Başlıca Finansal Tablo Kalemlerinin Tutarları ve Değişimleri

\begin{tabular}{l|c|c|c|c|c|c}
\hline & $\begin{array}{c}\text { Dönem Kâr1 } \\
(\mathrm{TL})\end{array}$ & $\begin{array}{c}\text { Finansman } \\
\text { Gideri Öncesi } \\
\text { Faaliyet Kâr1 } \\
(\mathrm{TL})\end{array}$ & $\begin{array}{c}\text { Esas Faaliyet } \\
\text { Kâr1 } \\
(\mathrm{TL})\end{array}$ & $\begin{array}{c}\text { Faiz Gideri } \\
(\mathrm{TL})\end{array}$ & $\begin{array}{c}\text { Toplam Varlıklar } \\
(\mathrm{TL})\end{array}$ & $\begin{array}{c}\text { Toplam } \\
\text { Yükümlülükler } \\
(\mathrm{TL})\end{array}$ \\
\hline TMS 17 & 9.316 .048 .600 & 19.793 .564 .341 & 17.941 .670 .144 & 11.008 .710 .944 & 235.835 .014 .052 & 149.996 .790 .360 \\
\hline IFRS 16 & 8.987 .360 .343 & 22.422 .369 .701 & 20.570 .475 .504 & 14.048 .376 .626 & 260.023 .335 .128 & 173.524 .721 .451 \\
\hline Jeğişim (\%) & $(3,53)$ & 13,28 & 14,65 & 27,61 & 10,26 & 15,69 \\
\hline
\end{tabular}

İncelenen bir diğer nokta da 16 şirketin TMS 17 ve TFRS 16 uygulanması durumunda finansal oranları ve finansal oranlardaki değişimdir. TFRS 16 'nin etkisi Tablo 5'de sunulmuştur.

\section{Tablo 5. TMS 17 ve TFRS 16'ya Göre Finansal Oranlar ve Değişimleri}

\begin{tabular}{|l|c|c|c|c|}
\hline & $\begin{array}{c}\text { Aktif Kârlılı̆̆1 } \\
(\%)\end{array}$ & $\begin{array}{c}\text { Toplam Borç/ } \\
\text { Toplam Varlıklar } \\
(\%)\end{array}$ & $\begin{array}{c}\text { Net Kâr Marji } \\
(\%)\end{array}$ & $\begin{array}{c}\text { Faaliyet Kâr } \\
\text { Marji } \\
(\%)\end{array}$ \\
\hline TMS 17 & 3,95 & 63,60 & 5,79 & 11,14 \\
\hline TFRS 16 & 3,46 & 66,73 & 5,58 & 12,78 \\
\hline Değișim & $(0,49)$ & 3,13 & $(0,21)$ & 1,64 \\
\hline
\end{tabular}

TFRS 16'nın tüm örnekleme olan etkisi Tablo 4 ve Tablo 5'te sunulduktan sonra 16 şirket sektörlerine göre ayrılmıştır. Aşağıdaki tabloda hangi sektörde kaç adet şirketin bulunduğu sunulmuştur.

Tablo 6. Sektörlere Göre Şirket Sayısı

\begin{tabular}{|l|c|}
\hline Sektör & $\begin{array}{c}\text { Şirket } \\
\text { Sayıs }\end{array}$ \\
\hline İmalat & 5 \\
\hline Ulaştırma, Haberleşme ve Depolama & 4 \\
\hline Toptan ve Perakende Ticaret, Otel ve Lokantalar & 3 \\
\hline İnşaat ve Bayındırlık & 2 \\
\hline Eğitim, Sağllk, Spor ve Diğer Sosyal Hizmetler & 1 \\
\hline Teknoloji & 1 \\
\hline Toplam & $\mathbf{1 6}$ \\
\hline
\end{tabular}


Çalışmanın devamında TFRS 16 standardının finansal tablo kalemleri ve finansal oranlara etkisi sektörel açıdan incelenecektir. İnceleme yapılırken örneklemde 3'den az sayıda şirket ile yer alan sektörler dikkate alınmamıştır.

\section{TFRS 16'nin Etkisinin Sektörlere Göre Ölçülmesi}

Örneklemde 5 adet şirket ile en fazla üretim sektöründe faaliyet gösteren şirketler yer almıştır. Tüm örneklem için yapılan analiz bu kez sadece üretim sektöründe yer alan şirketler için yapılarak TFRS 16'nın başlıca finansal tablo kalemleri ve finansal oranlara etkisi Tablo 7 ve Tablo 8'de sunulmuştur.

Tablo 7. TMS 17 ve TFRS 16'ya Göre Üretim Sektörü Şirketlerinin Başlıca Finansal Tablo Kalemlerinin Tutarları ve Değişimleri

\begin{tabular}{l|c|c|c|c|c|c}
\hline & $\begin{array}{c}\text { Dönem Kâr1 } \\
(\mathrm{TL})\end{array}$ & $\begin{array}{c}\text { Finansman } \\
\text { Gideri Öncesi } \\
\text { Faaliyet Kâr1 } \\
(\mathrm{TL})\end{array}$ & $\begin{array}{c}\text { Esas Faaliyet } \\
\text { Kâr1 } \\
(\mathrm{TL})\end{array}$ & $\begin{array}{c}\text { Faiz Gideri } \\
(\mathrm{TL})\end{array}$ & $\begin{array}{c}\text { Toplam Varlıklar } \\
(\mathrm{TL})\end{array}$ & $\begin{array}{c}\text { Toplam } \\
\text { Yükümlülükler } \\
(\mathrm{TL})\end{array}$ \\
\hline TMS 17 & 1.665 .490 .492 & 2.969 .583 .038 & 3.428 .427 .299 & 924.587 .326 & 44.073 .192 .046 & 28.328 .338 .568 \\
\hline TFRS 16 & 1.689 .410 .770 & 3.024 .302 .086 & 3.483 .146 .347 & 949.406 .026 & 44.270 .688 .334 & 28.507 .058 .221 \\
\hline Jeğişim (\%) & 1,44 & 1,84 & 1,60 & 2,68 & 0,45 & 0,63 \\
\hline
\end{tabular}

Tablo 8. TMS 17 ve TFRS 16'ya Göre Üretim Sektörü Şirketlerinin Finansal Oranları ve Değişimleri

\begin{tabular}{|l|c|c|c|c|}
\hline & $\begin{array}{c}\text { Aktif Kârllı̆̆ğ1 } \\
(\%)\end{array}$ & $\begin{array}{c}\text { Toplam Borç/ } \\
\text { Toplam Varlıklar } \\
(\%)\end{array}$ & $\begin{array}{c}\text { Net Kâr Marj1 } \\
(\%)\end{array}$ & $\begin{array}{c}\text { Faaliyet Kâr } \\
\text { Marji } \\
(\%)\end{array}$ \\
\hline TMS 17 & 3,78 & 64,28 & 4,68 & 9,64 \\
\hline TFRS 16 & 3,82 & 64,39 & 4,75 & 9,79 \\
\hline Değisim & 0,04 & 0,12 & 0,07 & 0,15 \\
\hline
\end{tabular}

Tablo 9 ve Tablo 10'da TFRS 16'nın Ulaştırma, Haberleşme ve Depolama sektöründeki şirketlerin başlıca finansal tablo kalemleri ve finansal oranlarına etkisi sunulmuştur.

Tablo 9. TMS 17 ve TFRS 16'ya Göre Ulaştırma, Haberleşme ve Depolama Sektörü Şirketlerinin Başlıca Finansal Tablo Kalemlerinin Tutarları ve Değişimleri

\begin{tabular}{l|c|c|c|c|c|c}
\hline & $\begin{array}{c}\text { Dönem Kârı } \\
(\mathrm{TL})\end{array}$ & $\begin{array}{c}\text { Finansman } \\
\text { Gideri Öncesi } \\
\text { Faaliyet Kârı } \\
(\mathrm{TL})\end{array}$ & $\begin{array}{c}\text { Esas Faaliyet } \\
\text { Kârı } \\
(\mathrm{TL})\end{array}$ & $\begin{array}{c}\text { Faiz Gideri } \\
(\mathrm{TL})\end{array}$ & $\begin{array}{c}\text { Toplam Varlıklar } \\
(\mathrm{TL})\end{array}$ & $\begin{array}{c}\text { Toplam } \\
\text { Yükümlülükler } \\
(\mathrm{TL})\end{array}$ \\
\hline TMS 17 & 4.313 .354 .098 & 12.225 .808 .157 & 10.931 .695 .202 & 8.324 .986 .156 & 139.866 .075 .517 & 97.610 .262 .311 \\
\hline TFRS 16 & 3.181 .540 .777 & 13.323 .632 .505 & 12.029 .519 .550 & 10.837 .577 .156 & 159.860 .168 .352 & 117.460 .876 .860 \\
\hline Jeğişim (\%) & $(26,24)$ & 8,98 & 10,04 & 30,18 & 14,30 & 20,34 \\
\hline
\end{tabular}

Tablo 10. TMS 17 ve TFRS 16'ya Göre Ulaştırma, Haberleşme ve Depolama Sektörü Şirketlerinin Finansal Oranları ve Değişimleri

\begin{tabular}{|l|c|c|c|c|}
\hline & $\begin{array}{c}\text { Aktif Kârllı̆̆ğ1 } \\
(\%)\end{array}$ & $\begin{array}{c}\text { Toplam Borç/ } \\
\text { Toplam Varlıklar } \\
(\%)\end{array}$ & $\begin{array}{c}\text { Net Kâr Marji } \\
(\%)\end{array}$ & $\begin{array}{c}\text { Faaliyet Kâr } \\
\text { Marji } \\
(\%)\end{array}$ \\
\hline TMS 17 & 3,08 & 69,79 & 5,37 & 13,61 \\
\hline TFRS 16 & 1,99 & 73,48 & 3,96 & 14,98 \\
\hline Değișim & $(1,09)$ & 3,69 & $(1,41)$ & 1,37 \\
\hline
\end{tabular}


Tablo 11 ve Tablo 12'de TFRS 16'nın Toptan ve Perakende Ticaret, Otel ve Lokantalar sektöründeki şirketlerin başlıca finansal tablo kalemleri ve finansal oranlarına etkisi sunulmuştur.

Tablo 11. TMS 17 ve TFRS 16'ya Göre Toptan ve Perakende Ticaret, Otel ve Lokantalar Sektörü Şirketlerinin Başlıca Finansal Tablo Kalemlerinin Tutarları ve Değişimleri

\begin{tabular}{l|c|c|c|c|c|c}
\hline & $\begin{array}{c}\text { Dönem Kâr1 } \\
(\mathrm{TL})\end{array}$ & $\begin{array}{c}\text { Finansman } \\
\text { Gideri Öncesi } \\
\text { Faaliyet Kâr1 } \\
(\mathrm{TL})\end{array}$ & $\begin{array}{c}\text { Esas Faaliyet } \\
\text { Kâr1 } \\
(\mathrm{TL})\end{array}$ & $\begin{array}{c}\text { Faiz Gideri } \\
(\mathrm{TL})\end{array}$ & $\begin{array}{c}\text { Toplam Varlıklar } \\
\text { (TL) }\end{array}$ & $\begin{array}{c}\text { Toplam } \\
\text { Yükümlülükler } \\
\text { (TL) }\end{array}$ \\
\hline TMS 17 & 744.568 .000 & 1.976 .465 .000 & 905.447 .000 & 1.303 .857 .000 & 16.396 .367 .000 & 13.401 .304 .000 \\
\hline TFRS 16 & 1.996 .431 .839 & 3.622 .650 .480 & 2.551 .632 .480 & 1.385 .212 .681 & 17.043 .759 .684 & 13.934 .298 .885 \\
\hline Teğişim (\%) & 168,13 & 83,29 & 181,81 & 6,24 & 3,95 & 3,98 \\
\hline
\end{tabular}

Tablo 12. TMS 17 ve TFRS 16'ya Göre Toptan ve Perakende Ticaret, Otel ve Lokantalar Sektörü Şirketlerinin Finansal Oranları ve Değişimleri

\begin{tabular}{|l|c|c|c|c|}
\hline & $\begin{array}{c}\text { Aktif Kârllı̆̆g } \\
(\%)\end{array}$ & $\begin{array}{c}\text { Toplam Borç/ } \\
\text { Toplam Varlıklar } \\
(\%)\end{array}$ & $\begin{array}{c}\text { Net Kâr Marj1 } \\
(\%)\end{array}$ & $\begin{array}{c}\text { Faaliyet Kâr } \\
\text { Marji } \\
(\%)\end{array}$ \\
\hline TMS 17 & 4,54 & 81,73 & 2,49 & 3,03 \\
\hline TFRS 16 & 11,71 & 81,76 & 6,68 & 8,54 \\
\hline Değișim & 7,17 & 0,03 & 4,19 & 5,51 \\
\hline
\end{tabular}

\section{Analizin Sonuçları}

Analizin ilk aşamasında finansal tablo dipnotlarında faaliyet kiralamaları hakkında tutar ve vade bilgisi raporlamış olan 16 şirket bir arada incelenmiştir. İncelemede şirketlerin 2017 yılında TMS 17 yerine TFRS 16 standardını kullandığı varsayılmıştır. Böylece hem TMS 17 hem TFRS 16'ya göre ilgili finansal tablo kalemleri ve finansal oranlardaki etkiyi görmek mümkün olmuştur. Tüm örneklem ele alındığında TFRS 16 standardının dönem kârı üzerinde \%3,53 oranında azalış, finansman giderleri öncesi faaliyet kârında \% 13,28, esas faaliyet kârında \% 14,65 , faiz giderlerinde $\% 27,61$, toplam varlıklarda $\% 10,26$, toplam yükümlülüklerde ise $\%$ 15,69 artı̧̧ yarattığı tespit edilmiştir.

Esas faaliyet kârındaki artışın nedeni TMS 17 standardına göre faaliyet kiralamasından kaynaklanan kira giderlerinin TFRS 16 standardında gelir tablosuna etkisinin olmadığının varsayılmasıdır. TFRS 16 standardında faaliyet kiralamaları varlıklarda ve yükümlülüklerde raporlandığı için dönemsel olarak kira gideri değil amortisman ve faiz gideri yaratmaktadır. TMS 17’ye göre gelir tablosunda toplam 5.316.396.591 TL kira gideri raporlanmıştır. TFRS 16 uygulandığı varsayımında ise söz konusu kira gideri gelir tablosunda yer almayacaktır. Ancak TFRS 16'ya göre kullanım hakkı varlığın 2017 yılı amortisman gideri tutarı olan 2.687.591.231 TL'nin gelir tablosunda raporlanması gerekecektir. Bu tutarlar arasındaki fark olan 2.628.805.360 TL, esas faaliyet kârındaki artışı (\% 14,65) açıklamaktadır. Benzer bir durum finansman gideri öncesi faaliyet kârında da görülmekte ve \% 13,28’lik artış yaratmaktadır. TFRS 16 'ya göre yükümlülük olarak raporlanan kiralama borçları faiz giderine neden olmaktadır. $\mathrm{Bu}$ durum 2017 yılında faiz giderlerinde yaklaşık 3,03 milyar TL $(\% 27,61)$ artış yaratmaktadır. Dönem net kârında meydana gelen azalış ise TFRS 16 uygulanması durumunda gelir 
tablosunda yer alan amortisman gideri ve finansman giderlerindeki artışların, gelir tablosu dışında bırakılan faaliyet kiralaması giderinden daha fazla olmasından kaynaklanmaktadır. TFRS 16 kapsamında, faaliyet kiralamalarının bilançoda raporlanması 2017 yılı sonunda toplam varlık ve toplam yükümlülüklerde yaklaşık 24 milyar TL artışa neden olmuştur.

Finansal oranlardaki değişimler incelendiğinde net kâr marjında azalma görülmektedir. TFRS 16 uygulandığında dönem kârı azalmaktadır bundan dolayı net kâr marjı da olumsuz etkilenmektedir. Bir diğer azalış da aktif kârlılığındadır. TFRS 16 uygulanması dönem kârını azaltmakta, toplam varlıkları ise arttırmaktadır. Bu etki aktif kârlılığına da olumsuz olarak yansımıştır. Faaliyet kâr marjında ise olumlu yönde bir artış tespit edilmiştir. Faaliyet kiralaması giderlerinin TFRS 16'da dikkate alınmaması esas faaliyet kârını arttırmış bu durum da faaliyet kâr marjındaki artışa neden olmuştur. 2017 yılı sonunda toplam borç/toplam varlık oranı da artmıştır. TFRS 16'nın finansal oranlara olan etkisi Lee, Paik ve Yoon (2014), Ericson ve Skarphagen (2015), Wong ve Joshi (2015)'nin çalışmalarının sonuçları ile paralellik göstermektedir.

TFRS 16 standardının etkisi sektörel olarak da ele alınmıştır. Örneklemde yer alan 5 üretim şirketinin finansal tablo kalemlerindeki değişimler incelendiğinde dönem kârında \% 1,44, finansman gideri öncesi faaliyet kârında \% 1,84, esas faaliyet kârında \% 1,60, faiz giderlerinde $\%$ 2,68, toplam varlıklarda \% 0,45, toplam yükümlülüklerde ise $\% 0,63$ artış tespit edilmiştir. Üretim sektörü incelendiğinde dönem kârındaki etkinin örneklemin bütününden farklı olduğu görülmektedir ve TFRS 16 uygulanması dönem kârında yaklaşık 24 milyon artışa neden olmaktadır. Bunun nedeni bu sektörde TFRS 16'nın yarattığı amortisman gideri ve finansman giderlerindeki artışın kira giderindeki düşüşten daha az olmasıdır. Örneklemin bütünü ile paralel olarak diğer finansal tablo kalemlerinde artış söz konusudur. Üretim sektöründeki finansal oranların değişimi incelendiğinde toplam borç/toplam varlık oranı ile faaliyet kâr marjı oranının örneklemin bütününe benzer şekilde arttığg görülmüştür. Ancak aktif kârlılığı ve net kâr marjında da örneklemin bütününden farklı olarak artış vardır. Bu durumun nedeni üretim sektöründe TFRS 16'nın dönem kârını arttırıcı etki yapmasıdır.

İncelenen bir diğer sektör ulaştırma, haberleşme ve depolama sektörüdür. Bu sektörde finansal tablo kalemlerinde TFRS 16'nın yarattığı rakamsal değişimler diğer sektörlere göre daha yüksektir. Bunun nedeni bu sektörde Türk Hava Yolları ve Pegasus gibi hava yolu taşımacıllı̆ı yapan ve uçakları için sıklıkla faaliyet kiralaması yapan şirketlerin varlığıdır. Bu sektörde finansal tablo kalemleri incelendiğinde dönem kârında \% 26,24 azalış, finansman gideri öncesi faaliyet kârında \% 8,98, esas faaliyet kârında \% 10,04, faiz giderlerinde \% 30,18, toplam varlıklarda \% 14,30 ve toplam yükümlülüklerde \% 20,34 artış tespit edilmiştir. Finansman giderleri öncesi kârda TFRS 16 uygulandığında artış varken, dönem kârında azalış mevcuttur. Bunun nedeni kiralanan uçakların kiralama borçlarının yükümlülük olarak raporlanmasının yarattığı finansman giderlerindeki yaklaşık 2,5 milyar TL'lik artıştır. Özellikle sektörde yer alan hava yolu şirketlerinin faaliyet kiralaması yaptıkları uçakları TFRS 16'ya göre varlık ve yükümlülük olarak raporlamaları gerektiğinden ve uçakların yüksek değere sahip varlıklar olmasından dolayı sektörün toplam varlık ve toplam yükümlülüklerinde yaklaşık 20 milyar TL 
artış olmaktadır. Finansal oranlar incelendiğinde Aktif kârlılığı ve net kâr marjında azalış görülmektedir. Bu duruma yükselen finansman giderleri neden olmaktadır. Azalan faaliyet kiralaması giderlerinin etkisiyle de faaliyet kâr marjı TFRS 16 uygulandığında artmaktadır.

Çalışmada incelenen son sektör ise toptan ve perakende ticaret, otel ve lokantalar sektörüdür. Sektörde yer alan şirketlerin finansal tablo kalemleri incelendiğinde; dönem kârı \% 168,13, finansman öncesi faaliyet kârı \% 83,29, esas faaliyet kârı \%181,81, faiz giderleri \%6,24, toplam varlıklar \%3,95, ve toplam yükümlülükler \% 3,98 artmıştır. Dönem kârında, finansman gideri öncesi faaliyet kârında ve esas faaliyet kârında yüzdesel olarak önemli değişimler görülmektedir. Bu durumun nedeni 2017 yılında TFRS 16'ya göre gelir tablosuna dâhil edilmemiş faaliyet kiralaması giderlerinin çok yüksek olmasıdır. Sektöre ait finansal oranların tamamında artış tespit edilmiştir. Özellikle kârlılık oranlarında önemli artış görülmektedir ve bu durum Fülbier, Silva ve Pferdehirt (2008)'ün çalışması ile de paralellik göstermektedir. Kârlılık oranlarındaki artışların başlıca nedeni; dönem kârındaki yükseliştir. TFRS 16'nın etkisini gösteren özet tablo aşağıda sunulmuştur.

\section{Tablo 13. TFRS 16’nın Başlıca Finansal Tablo Kalemlerine ve Finansal Oranlara Etkisi}

\begin{tabular}{|c|c|c|c|c|c|c|c|c|c|c|}
\hline & $\begin{array}{l}\text { Dönem } \\
\text { Kârı }\end{array}$ & $\begin{array}{l}\text { Finansman } \\
\text { Gideri } \\
\text { Öncesi } \\
\text { Faaliyet } \\
\text { Kârı }\end{array}$ & $\begin{array}{c}\text { Esas } \\
\text { Faaliyet } \\
\text { Kâr1 }\end{array}$ & $\begin{array}{l}\text { Faiz } \\
\text { Gideri }\end{array}$ & $\begin{array}{l}\text { Toplam } \\
\text { Varlıklar }\end{array}$ & $\begin{array}{c}\text { Toplam } \\
\text { Yükümlülükler }\end{array}$ & $\begin{array}{l}\text { Aktif } \\
\text { Kârllılığ1 }\end{array}$ & $\begin{array}{l}\text { Toplam } \\
\text { Borç / } \\
\text { Toplam } \\
\text { Varlıklar }\end{array}$ & $\begin{array}{c}\text { Net } \\
\text { Kâr } \\
\text { Marj1 }\end{array}$ & $\begin{array}{c}\text { Faaliyet } \\
\text { Kâr } \\
\text { Marj1 }\end{array}$ \\
\hline BİST 100 & Azalıș & Artış & Artış & Artıș & Artış & Artış & Azalıș & Artış & Azalıș & Artış \\
\hline Üretim Sektörü & Artış & Artış & Artış & Artış & Artış & Artış & Artış & Artış & Artış & Artış \\
\hline $\begin{array}{l}\text { Ulaştırma, } \\
\text { Haberleşme ve } \\
\text { Depolama } \\
\text { Sektörü }\end{array}$ & Azalış & Artış & Artış & Artış & Artış & Artış & Azalış & Artış & Azalış & Artış \\
\hline $\begin{array}{l}\text { Toptan ve } \\
\text { Perakende } \\
\text { Ticaret, Otel ve } \\
\text { Lokantalar } \\
\text { Sektörü } \\
\end{array}$ & Artış & Artış & Artış & Artış & Artış & Artış & Artış & Artış & Artış & Artış \\
\hline
\end{tabular}

\section{Sonuç}

Kiralama işlemlerinin ve özellikle de faaliyet kiralaması işlemlerinin finansal tablolarda nasıl raporlanacağı uzun zamandır üzerinde tartışılan bir konu olmuştur. 1.1.2018 tarihinde uygulanmaya başlayan TFRS 16 standardı ile faaliyet kiralamalarının kiracılar tarafından nasıl muhasebeleştirileceği ve finansal tablolarda raporlanacağı konusunda ciddi değişiklikler olmuştur. Bu çalışmada hem TFRS 16 standardı kiracılar açısından incelenmiş, hem muhasebe ve raporlama uygulamalarına ilişkin örnekler verilmiş hem de 2017 yılı verileri kullanılarak BİST 100'de yer şirketler üzerine bir inceleme yapılmıştır. BİST 100'de yer alan ve finansal kurum olmayan 63 şirketin 16 tanesinde faaliyet kiralaması bilgileri raporlanmaktadır. Örneklemi de bu 16 şirket oluşturmuştur.

İnceleme sonucunda 2017 yılı için tüm örneklemde TFRS 16'nın TMS 17’ye göre gerek finansal tablo kalemlerinde gerekse finansal oranlarda beklenildiği şekilde değişiklik yarattığı görülmüştür. Ancak sektörler açısında faaliyet kiralaması yapma sıklığının ve faaliyet 
kiralamasına konu olan varlıkların değerlerinin farklılaşabileceği göz önüne alınarak sektörel açıdan da inceleme yapılmıştır. Sektörel olarak bakıldığında ele alınan üç sektör içinde tutarlar açısından en önemli değişikliklerin ulaştırma, haberleşme ve depolama sektöründe olduğu görülmüştür. Hava yolu taşımacılığı şirketlerinin bu sektörde faaliyet gösterdiği göz önüne alındığında bu şaşırtıcı bir sonuç değildir. Bunun yanı sıra TFRS 16'nın sektörlere etkisinin farklı olacağı, kimi sektörler de finansal tablo kalemlerinde ve finansal oranlarda ciddi değişimler yaşanmazken özellikle faaliyet kiralamasını yoğunlukla ve yüksek değerli varlıklar için kullanan sektörlerde ciddi değişimler olması beklenebilir. Bu standardın kullanılmaya başlanması ile faaliyet kiralaması yapan şirketlerin sahip oldukları ancak TMS 17’ye göre raporlayamadıkları varlıklarını bilançosunda raporlama imkânları olacaktır. Aynı şekilde faaliyet kiralaması kaynaklı borçlarda yükümlülük olarak bilançoya alınacaktır. Bu sayede işletmeler arasında finansal tabloların karşılaştırılabilirliği artacak ve finansal oranlar daha anlamlı hale gelecektir. Bu durum ayrıca finansal tabloların gerçeğe uygun sunumunu güçlendirecek bir etki yaratacaktır.

TFRS 16 standardının BİST 100 üzerine etkisi incelenirken karşılaşılan kısıtlar olmuştur. Bunlardan ilki BİST 100'de yer alan ve finansal kurum olmayan 63 şirketten sadece 16 şirketin finansal tablo dipnotlarında faaliyet kiralaması ve faaliyet kiralaması giderlerine ilişkin bilgileri raporlamalarıdır. Bunun yanı sıra TFRS 16’nın henüz uygulanmadığı 2017 yılında uygulandığı şeklinde hareket edilebilmesi için bazı varsayımlar yapılması gerekmiştir. Bu varsayımların değiştirilmesi halinde sonuçlarda da değişimler olması olasıdır.

Gelecek çalışmalarda tüm BİST şirketleri kullanılarak araştırmanın anakütlesi genişletilebilir. Bunun yanı sıra TFRS 16'nın 2018 yılında kullanılmaya başlanması sonucunda TMS 17'nin kullanıldığ 1 dönemlere finansal tablolar ve TFRS 16'nin kullanıldı̆̆ 1 dönemlere ait finansal tablolar karşılaştırılarak yeni standardın etkisi ölçülmeye çalışabilir. Son olarak diğer ülkelerde halka açık şirketlerin TFRS 16 kullanılmaya başlandıktan sonraki finansal tabloları ile Türkiye'deki şirketlerin finansal tabloları karşılaştırılarak TFRS 16'nın etkisi ülkeler açısından da incelenebilir.

\section{Kaynakça}

Acar, M., Temiz, H., Aktaş, R. (2017). UMS 17 Kiralama işlemleri standardından UFRS 16'ya geçişin finansal tablolar üzerinde etkisi: Borsa İstanbul örneği. Muhasebe Bilim Dünyası Dergisi, 19(3), 592-623.

Aktaş, R., Karğın, S. \& Arıcı, N.D. (2017). Yeni kiralamalar standardı UFRS 16'nın getirdiği yenilikler ve işletmelerin finansal tablolarına ve finansal oranlarına olası etkilerinin değerlendirilmesi. Journal of Business Research Turk, 9(4), 858-881.

Altıntaş, T. \& Turel, A. (2016). Seçmeler 2016, İstanbul: Muhasebe Enstitüsü.

Aslan, Ü. (2018). UFRS 16 kiralamalar standardı kapsamında faaliyet kiralamalarının kiracı işletme tarafından muhasebeleştirilmesi ve raporlanması. Muhasebe ve Finansman Dergisi, 77, 55-68.

Beattie, V., Edwards, K. \& Goodacre, A. (1998). The impact of constructive operating lease capitalization on key accounting ratios. Accounting and Business Research, 28(4), 233254. 
Bennett, B.K. \& Beadbury, M.E. (2003). Capitalizing non-cancelable operating leases. Journal of International Finance Management and Accounting, 14(2), 101-114.

Demirci, Ş.D. \& Kıvraklar, M.K. (2018). Ulusal ve uluslararası düzenlemeler çerçevesinde finansal kiralama işlemlerinin muhasebeleştirilmesi. Muhasebe ve Vergi Uygulamaları Dergisi, 10.Yıl Özel Sayı, 508-531.

Disalvio, J. \& Dorata, N.T. (2014). Lease accounting change: It's not over yet. Review of Business: Special Accounting Issue, 35(1), 16-22.

Duke, J.C., Hsieh, S.J. \& Su, Y., (2009). Operating and synthetic leases: Exploiting financial benefits in the post-enron era, advances in accounting. Incorporating Advances in International Accounting, 25(1), 28-39.

Ericson, J. \& Skarphagen, R. (2015). Capitalization of operating lease and its impacts on financial ratios. Master Thesis, Jörköping University Jörköping International Business School.

Fulbier, R.U., Silva, J.L. \& Pferdehirt, M.H. (2008). Impact of lease capitalization on financial ratios of listed German companies. Schmalenbach Business Review, 60(2), 122-144.

Hazır, Ç.A. (2018). Kiralama işlemlerinin TFRS 16'ya göre muhasebeleştirilmesi ve ölçülmesi. Mali Çözüm, 149, 85-122.

Imhoff, E., Lipe, R. \& Wright, D. (1991). Operating leases: Impact of constructive capitalization. Accounting Horizons, 5(1), 51-63.

Lee, B., Paik, D.G. \& Yoon, S.W. (2014). The effect of capitalizing operating leases on the immediacy to debt covenant violations. Journal of Accounting and Finance, 14(6), 44-70.

Marşap, B., Yanık, S. (2018). IFRS 16 Kapsamında Kiralama İşlemlerinin Finansal Raporlamaya Etkisinin İncelenmesi. Muhasebe ve Finansman Dergisi, 80, 23-42.

Öztürk, C. (2016). UFRS 16 kiralama işlemleri standardının eski UMS 17 standardı ile karşılaştırılması ve Almanya ve Türkiye'de hisse senetleri halka açık olan hava yolu şirketlerinin finansal durumuna etkisi. Muhasebe Bilim Dünyası Dergisi, 18(1), 1-50.

Paik, D.G.H., Smith, J.A.L, Lee, B.B. \& Yoon, S.W. (2015). The relation between accounting information in debt covenants and operating leases. Accounting Horizons, 29(4), 969-996.

Sarı, E.S., Altıntaş, T. \& Taş, N. (2016). The effect of the IFRS 16: Constructive capitalization of operating leases in the Turkish retailing sector. Journal of Business, Economics and Finance, 5(1), 138-147.

Serçemeli, M. \& Öztürk, M. (2016). Yeni finansal raporlama standardı IFRS 16 kiralama işlemleri'nin getirdiği değişimler üzerine bir değerlendirme. Mali Çözüm, 135, 31-48.

Singh, A., (2010). Proposed lease accounting changes: Implications for the restaurant and retail industries, Journal of Hospitality \& Tourism Research, 36(3), 335-365.

Singh, A., (2011). A Restaurant case study of lease accounting impacts of proposed changes in lease accounting rules. International Journal of Contemporary Hospitality Management, 23(6), 820-839.

Sipahi, B. (2004). Leasing İşlemleri ve Muhasebesi, Türkmen Kitabevi, İstanbul.

Tai, B.Y. (2013). Constructive capitalization of operating leases in the Hong Kong fast-food industry. International Journal of Accounting and Financial Reporting, 3(1), 128-142.

TFRS 16: Kiralamalar

TMS 17: Kiralama İşlemleri

Wong, K. \& Joshi, M. (2015). The impact of lease capitalisation on financial statements and key ratios: Evidence from Australia. Australasian Accounting Business and Finance Journal, 9(3), 27-44. 